\title{
Cutmarks on Capsian Human Remains: Implications for Maghreb Holocene Social Organization and Palaeoeconomy
}

\author{
CAROLINE M. HAVERKORT AND DAVID LUBELL* \\ Department of Anthropology, University of Alberta, Edmonton, Canada
}

\begin{abstract}
In 1930, the remains of five adults, one subadult, and one infant were excavated from Site 12, a ca. 8000 BP Capsian escargotière in Algeria. Recently, cutmarks were found on several postcranial bones of each of the adult individuals. In an attempt to reconstruct the burial circumstances, archival materials including photographs and field notes were retrieved from the State Historical Society of Wisconsin and the Logan Museum at Beloit College, and a detailed study of the cutmarks was carried out.

The cutmarks are associated mostly with long bones and skulls, while two individuals show cutmarks on the thorax. Using theories relating secondary burial practices to a nomadic lifestyle, it is hypothesized that the individuals died away from camp. Initial preparations, while awaiting transport to Site 12, involved limited exposure, followed by decapitation, dismemberment, and possibly defleshing of the thorax and removal of the internal organs. At Site 12, a formal burial ceremony was conducted during which red ochre was used. In some cases the dismembered extremities were placed in the grave with the rest of the body, but several skulls and long bones are missing. It is not known what the missing bones were used for, although Capsian groups are known for modifying human bones for either utilitarian or ritual purposes.

This is the first time that cutmarks on human remains are reported for this area and period. The idea that Capsian people practiced decapitation and dismemberment has been suggested before, based on observations on other sites, however. Studies of human skeletal material from the Maghreb, often excavated decades ago, may therefore reveal similar types of evidence. It is suggested that such studies will contribute significantly to our understanding of Holocene Maghreb burial practices, and our ability to reconstruct social organization and palaeoeconomy. Copyright () 1999 John Wiley \& Sons, Ltd.
\end{abstract}

Key words: cutmarks; Capsian; burial practice; Maghreb, human skeletons

\section{Introduction}

During the 1930 excavation of Site 12, an Epipalaeolithic shell midden or escargotière in Algeria (Pond et al., 1938), the skeletal remains of five adults, one subadult, and one infant, were found. In 1994, a detailed study of the remains was initiated at the University of Alberta. The

\footnotetext{
* Correspondence to: Department of Anthropology, 13-15 HM Tory Building, University of Alberta, Edmonton, AB T6G 2H4, Canada.
}

Contract/grant sponsor: Faculty of Arts and the Central Research Fund, University of Alberta

Contract/grant sponsor: Izaak Walton Killam Memorial Scholarship

Contract/grant sponsor: Stichting Fonds Doctor Catharine van Tussenbroek discovery of several cutmarks on the upper cervical vertebrae of three of the five adults prompted a study of archival material stored at the Archives Division, State Historical Society of Wisconsin, and the Logan Museum, Beloit College (White et al., 1992). These materials included the field diaries of two graduate students (Lloyd Wilford and Ralph Brown), photographs showing some of the exposed skeletons, and a profile of the trench. A more detailed study of the remains revealed the presence of more cutmarks on bones of each of the adults.

The excavation of Site 12 precedes the 'modern cutmark age' by several decades, and modern standards of excavation, and the requirements for modern cutmark studies as out- 


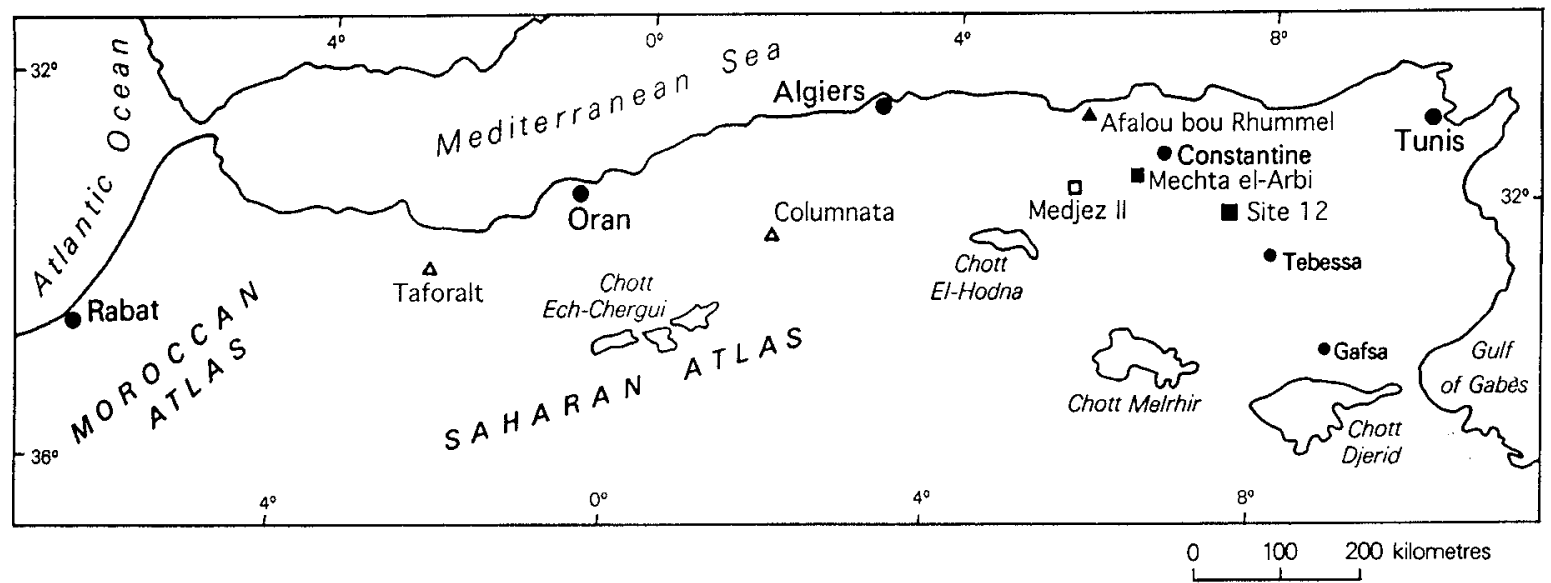

Figure 1. A map showing the location of Site 12, ca. $100 \mathrm{~km}$ southeast of Constantine. Triangles: Iberomaurusian, squares: Capsian.

lined by Villa (1992) are clearly not met. Nevertheless, we believe that the cutmarks found on the human remains from Site 12 provide unique new evidence on Capsian burial customs. In this paper we present the results of the study of the cutmarks and, using the various lines of evidence, we provide an interpretive framework for the findings and briefly discuss the implications for reconstruction and interpretation of Maghreb Holocene social organization and palaeoeconomy.

\section{The Logan Museum expeditions in North Africa}

Between 1925 and 1930, Alonzo Pond led a series of archaeological expeditions to North Africa sponsored by the Logan Museum of Anthropology at Beloit College (Pond et al., 1928, 1938). The research of these expeditions, which was very innovative for the time (Lubell, 1992; Sheppard, 1992) consisted of both excavation and survey concentrated on the high interior plateaux south of Constantine in Algeria. During the final (3 month) expedition in 1930, Pond took 14 American students along (including both Lauriston Sharp and Sol Tax) and treated the work that year as a field schoolprobably the first of its kind.

Pond and his team identified and mapped a large number of open air, cave and rockshelter sites in the region around Canrobert (now called Oum el Bouaghi) and Aïn Beïda. Almost all belong to what is today called the Capsian (Lubell et al., 1984), and the majority were mounds known as escargotières (Gobert, 1937) because the deposits in them are composed of dense concentrations of whole and broken land snail shells in addition to carbonized plant remains, mammalian bone, and bone and flint artefacts. Although more recent work has refined our understanding of the formation of these sites (Camps-Fabrer, 1975; Lubell et al., 1982-1983), the description of escargotière stratigraphy by Pond (1938) remains accurate:
... a group of refuse heaps welded into a single mound by centuries of wind and rain. It is com- posed of snail shells, camp fire ashes, hearth stones, animal bones and tools of bone and flint. It often contains human skeletons. Many present saucer-shaped depressions and hard-packed areas which seem to have been habitation floors. On many of these "floors" hearths or fire places, areas of burned stone, and deep beds of ashes are found. They are always located close to the banks of a lake or watercourse either modern or ancient'.

Site 12 (Figure 1) was chosen for excavation because it was the largest escargotière in the Canrobert region and there was a possibility that it was one of the few sites which might contain evidence of more than one archaeological culture (Pond, 1938). At the time, there was considerable speculation that the origins of the Aurignacian might lie in the Maghreb, and Pond was interested in the possibility (Shep- 
pard, 1987, 1992). Subsequent work by many archaeologists has shown this to be untenable. The escargotières contain lithic artefacts belonging to the Capsian, an early to midHolocene industry found in the Maghreb and of which there are several regional and temporal variants (Lubell et al., 1984; Sheppard \& Lubell, 1990). Analyses by Sheppard (1987) of the lithic artefacts from Site 12 have shown that there is a technological transition represented in the deposits which can be dated at ca. $8000 \mathrm{cal}$ $\mathrm{BP}$ on the basis of two radiocarbon dates (SMU 1132 \& 1135) run on charcoal samples collected by Pond in 1930 and conserved at the Logan Museum. This technological transition, which is in some ways equivalent to the distinction drawn between the Capsien typique and Capsien supérieure, is also related to the question of the biological affinities of late Pleistocene and early Holocene human populations in the Maghreb (see Lubell et al., 1984 for discussion).

Escargotières often contain human remains as complete or partial skeletons, isolated skulls, or fragments of bone (Pond, 1938; Camps-Fabrer, 1975). Pond (1938) discussed the question, then current, as to whether or not the human remains were intentionally buried. He believed that the 'distorted, flexed position, pell-mell and disconnected fragments' - in situ - were an indication that the Capsian people abandoned their deceased at the camp site, the actual 'burial' being the result of wind and weather. He also acknowledged the possibility that in some cases the body was temporarily disposed of at the time of death and that later the bones were collected for burial at the camp site. Since most of the remains were found in a distorted, flexed position or in a badly fragmented state, Pond believed that skeletons which were found in an extended position were generally to be regarded as more recent than the escargotière (Pond, 1938). More recent excavators have not been so prone to exclude such burials. Camps-Fabrer (1975), who has published one of the only complete monographs on a modern excavation of an escargotière, makes the point well: 'On a trop souvent, je crois, rejeté tous les squelettes trouvés en position allongée dans les gisement capsiens.'
At Site 12, one skeleton was found 'which had seemingly been decapitated and the head buried with the rest of the body' (Pond, 1938). This individual was discovered by a team from the University of Minnesota, directed by Albert Jenks and working in collaboration with the Logan Museum group. Jenks was assisted by two of his graduate students, Lloyd Wilford and Ralph Brown (Jenks \& Johnson, 1992). Jenks, Wilford and Brown independently excavated a second trench in which they discovered eight human burials, one of which (labelled 3A-4) was interpreted as intrusive because it was extended rather than flexed. Except for a brief note in Science, the work conducted by the University of Minnesota team was never published (Jenks, 1930; Jenks \& Johnson, 1992). Wilford described the human remains and undertook a detailed anthropometric analysis, but the manuscript (which bears Jenks' name) remained in the Minnesota files until we retrieved it.

It has been suggested previously that decapitation and dismemberment were practiced in Holocene Maghreb cultures (Bardin, 1953; Bayle des Hermens, 1955; Tixier, 1955; Camps \& Camps-Fabrer, 1972). The discovery of cutmarks on human remains from this region and period provides a unique opportunity to verify these statements and to gain a better understanding of the burial circumstances.

Cutmark studies: secondary burial or cannibalism?

In the past two decades, studies of cutmarks on bones (both animal and human) have added important new insights into certain behavioural aspects of prehistoric peoples. Detailed studies of cutmarks on faunal remains associated with early hominids have provided important information about the hunting and scavenging of our ancestors. Such studies have increased our understanding of techniques of processing animal carcasses, and of various uses of animal remains (Bunn, 1981; Potts \& Shipman, 1981; Wilson, 1982; Shipman \& Rose, 1983a,b; Shipman, 1986; Lyman, 1987).

Cutmarks on human bones have been associated with a variety of practices. Examples include decapitation, dismemberment, ritual 
sacrifices, violent death and secondary burial (Molleson, 1981; Larsson, 1984 1990; Bennike, 1985; Bush \& Stirland, 1991; McKinley, 1993; see Larsen, 1997 for a recent review of studies of skeletal trauma associated with injury and violent death). In many cases of sacrificial or violent death or decapitation, the contextual evidence leaves no doubt as to the circumstances of death, although confusion can arise in the case of secondary burial. Preparation of bodies for secondary burial may involve disarticulation, defleshing and extensive cleaning of bones and bone breakage (Huntington \& Metcalf, 1979; Russell, 1987), which may leave traces on the bones that strongly resemble those found on the remains of butchered animals. Thus, cutmarks on human remains have been the subject of considerable debate which has centred on two opposing, though not mutually exclusive, hypotheses: secondary burial (involving manipulation of the body prior to burial) and cannibalism (Trinkaus, 1985; Russell \& LeMort, 1986; Villa et al., 1986; White, 1986; Russell, 1987; Villa, 1992). Although these two ideas have been debated since the second half of the 19th century (Villa, 1992), the discovery of cutmarks has fuelled the debate and provided much additional information. Similarities in the treatment of food animals and human remains, especially with regard to butchering techniques, fracturing for marrow extraction, and the pattern of postprocessing discard, have all been cited as essential evidence for cannibalism. An additional criterion to aid in distinguishing between the two options - information about local burial practices - was added later (Villa et al., 1986; see Villa, 1992 for a review). Therefore, the spatial distribution of the remains and the nature of the deposit provide key pieces of evidence in this discussion.

\section{SITE 12}

Excavation of Site 12 (as reconstructed from archival resources)

In the absence of a published report by Jenks and/or his students, we must rely on the unpub- lished section drawing, the descriptions in the field notes and the diaries, and the monograph by Pond et al. (1938) in which the excavation of Site 12 by the Logan Museum group is discussed.

The section drawing shows a trench of $60 \mathrm{ft}$ long by $9.5 \mathrm{ft}$ wide, from the edge to the centre of the mound (Figure 2). Brown and Wilford worked simultaneously down as well as forward, from the edge to the centre, while they defined three arbitrary layers ('Below Floor', 'Middle' and 'Shell' or 'First level'). In doing so, they were following Pond's excavation methods (which in Trench A included arbitrary levels of $60 \mathrm{~cm}$ depth). While deficient by today's standards, these were fairly advanced for their day. Excavation was carried out with shovels, the dirt was collected in wheelbarrows and emptied outside the trench, and all deposit removed was sieved through $\frac{1}{4}$ in. mesh gravel screens set at a steep angle. Pond recorded this using both still and motion pictures, much of which has been preserved (Tarabulski \& Teicher, 1986). When human remains were discovered, excavation methods and tools were modified, with small paint brushes, fine hooks, orange wood sticks and careful observation used (Pond, 1938). From the diaries, field notes, and photographs, it is clear that Jenks' team used similar procedures.

\section{Burial circumstances}

The human remains were found in separate locations within each of the levels and thus represent events separated in time rather than a single event. The descriptions here are based on the unpublished profile and field notes by Wilford (unpublished field notes and diary).

Skeleton $3 A-1$ is that of an adult female, buried partly through a hearth or floor made of clay, mixed with ashes, charcoal and some red ochre. Some yellowish clay, unmixed with ashes and charcoal, was at both sides. Two feet to the north of the skeleton was an area of one foot squared heavily mixed with red ochre. As can be seen in Figure $3 \mathrm{~A}$ the upper body-from pelvis to upper vertebrae - was resting on its ventral surface. The left arm was folded under the torso, while the right arm lay back along the right side 


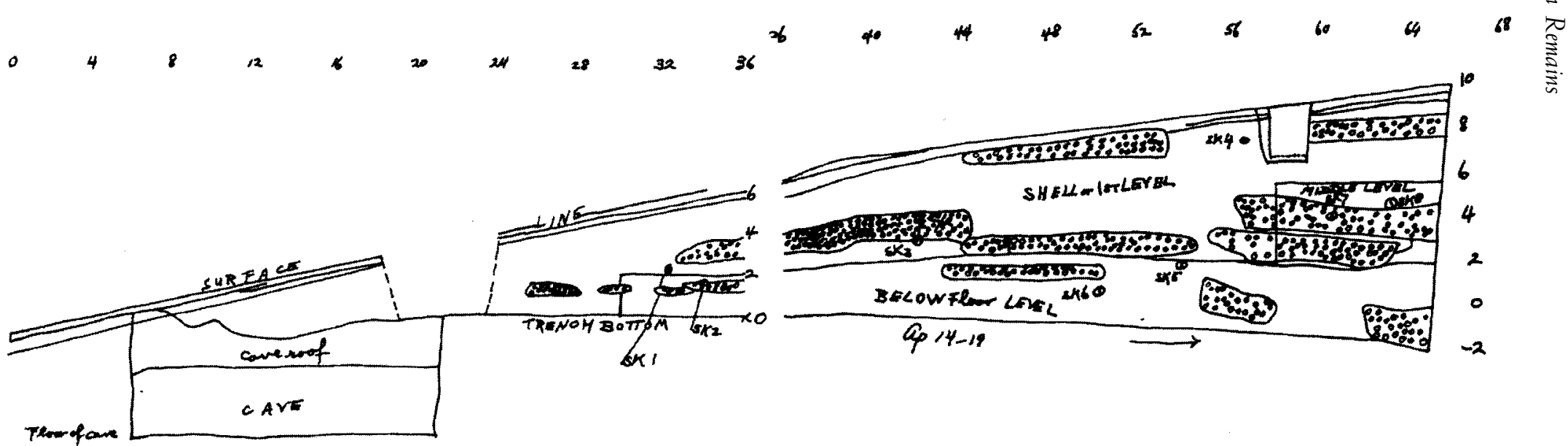

Figure 2. A hand-drawn profile of the trench, showing the arbitrary excavation levels, and the location of the human burials. SK = skeleton. SK4 was considered intrusive and these remains have not been included in this study. (Original held at Department of Anthropology, University of Minnesota, Minneapolis.) 


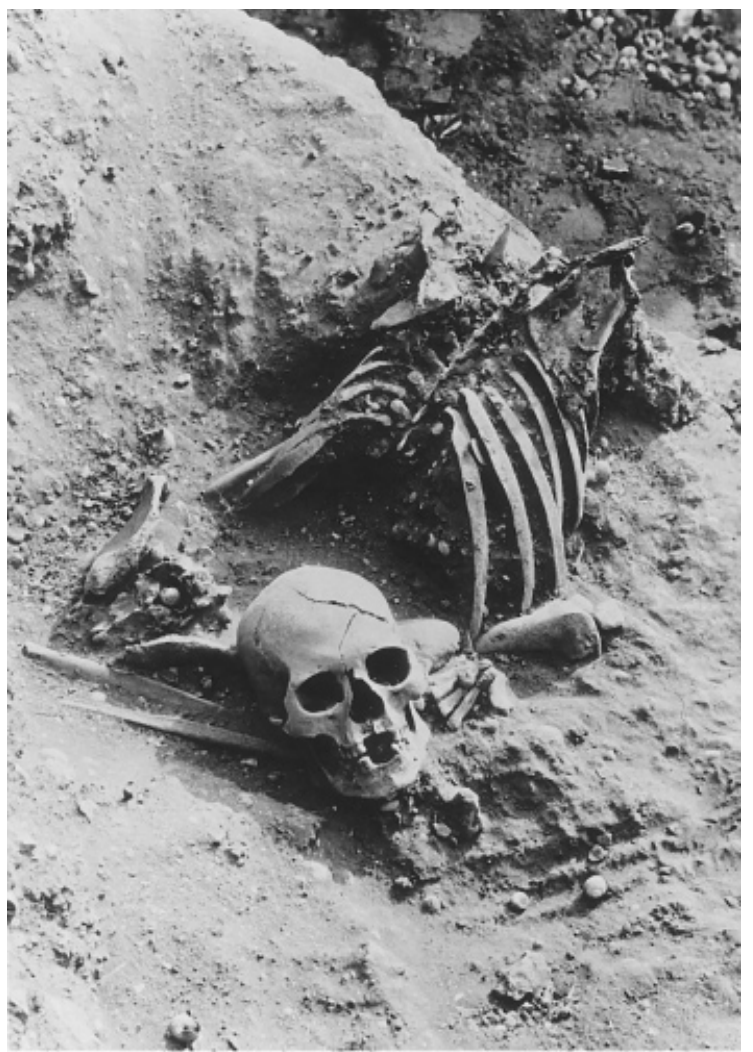

(A)

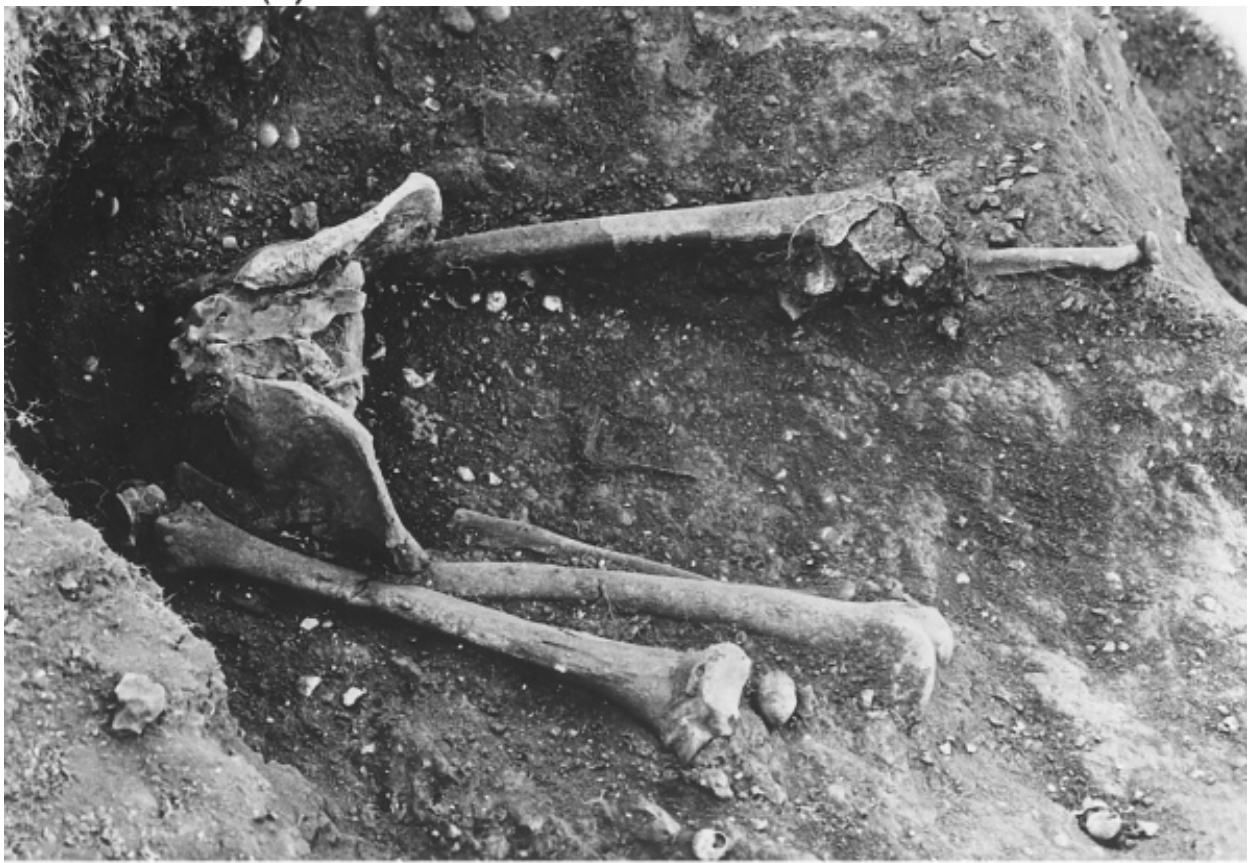

(B)

Figure 3. (A) Skeleton 3A-1 exposed (negative 30-10g: Logan Museum, Beloit College). 'It was undoubtedly decapitated, and the arms and legs were in peculiar positions but the torso was undoubtedly buried as a unit' (Wilford, unpublished field notes and diary). Tooth evulsion was a characteristic cultural practice. (B) The lower body of skeleton 3A-1 exposed after lifting of the torso, showing the displacement of the left tibia (negative 30-106: Logan Museum, Beloit College). 


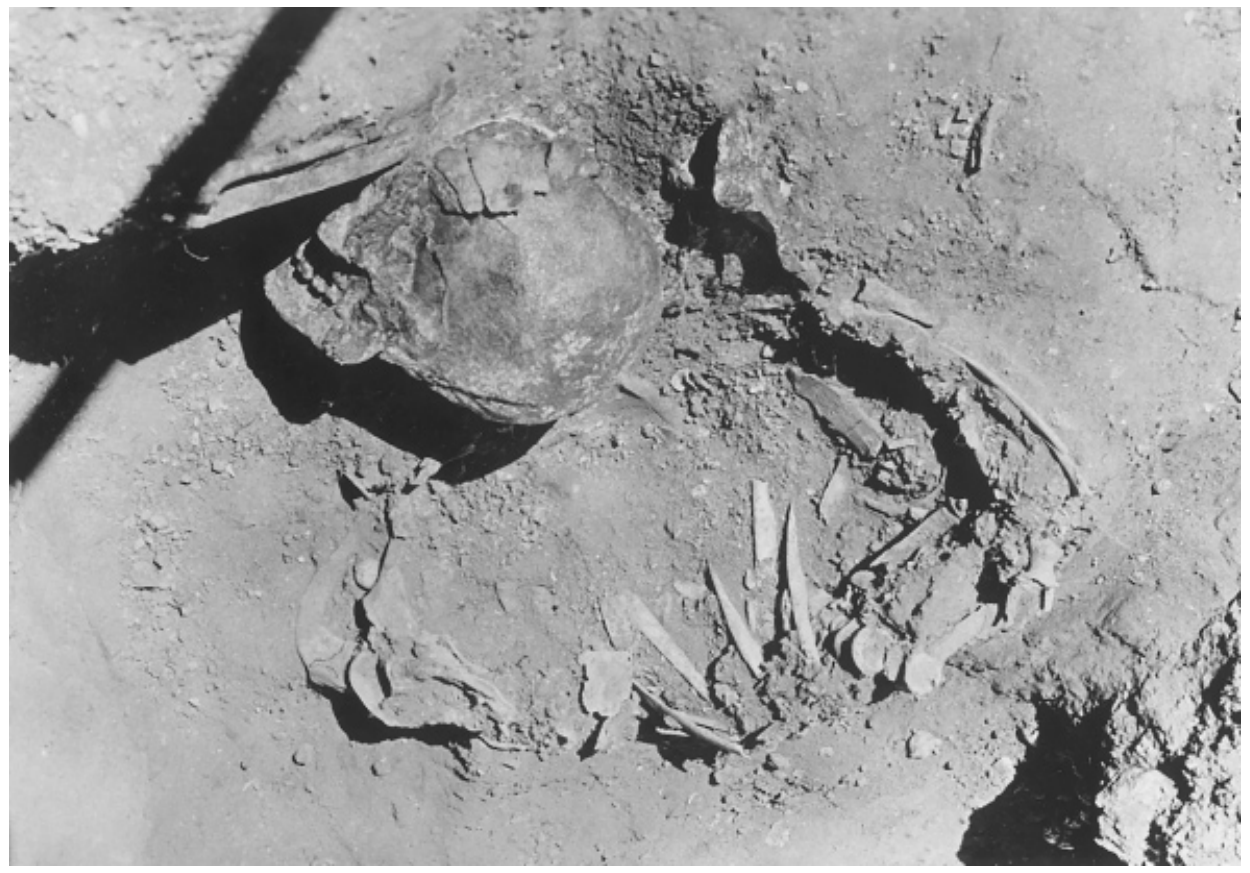

Figure 4. Skeleton 3A-2 (negative 30-114: Logan Museum, Beloit College): 'General position has effect of circle, the left scapula at $E$ end with vertebrae curving back to $W$ and then $N$ with pelvis tipped out of position at $N$ end of circle [ . . . N None of the long bones found except lower right arm' (Wilford, unpublished field notes and diary).

of the body. The body was fully flexed with both femora positioned under the torso, but while the right lower leg was in place along the right side of the pelvis, the lower left leg was out of place, the ends being reversed and lying diagonally across the pelvis (Figure $3 \mathrm{~B}$ ). The skull with mandible was out of place, resting on its occiput on the right side of the body (Figure $3 \mathrm{~A})$. There was a large rock under the left side of the skull. This is the individual referred to by Pond (1938) as having been 'seemingly decapitated'.

Skeleton 3A-2, also that of an adult, probably female, was buried on its right side in the Below Floor level. The hard floor layer above it was broken. The material surrounding the skeleton contained much ash and red ochre, with a large ochre deposit behind the skull. The general position of the remains was described as having 'the effect of a circle', with the vertebral column curving around (Figure 4). The remains were poorly preserved: the pelvis, ribs and vertebrae were 'crumbled and broken and the skull crushed'. The skull was lying 'at the east side of the circle between scapula and pelvis', on its right side and facing away from the body. Of the long bones, only the lower right arm was recovered.

Skeleton 3A-3, a subadult of about 11 years, was found lying on its right side in a fully flexed position with the knees close to the shoulders. No cutmarks have been found on the bones of this individual. There was no red ochre in association with the skeleton, although 'one fine flint blade at feet of squelette' was found. A similar absence of ochre was noted for Skeleton $3 A-8$, a ca. 1-month-old infant. As with the subadult, no cutmarks have been observed on the bones of this infant. Parts of the vertebrae, long bones, pelvis and phalanges were found, but the skull is missing.

Skeleton 3A-5, an adult male, was found in a reclining position, resting on its back with the legs half flexed and the femora pointing up (Figure 5). Both humeri rested at the sides of the body, the left forearm crossing the body and the right forearm bending back to the right shoulder. The skull was found above the pelvis between the left humerus and left femur, resting on its frontal with the mandible in place and the 


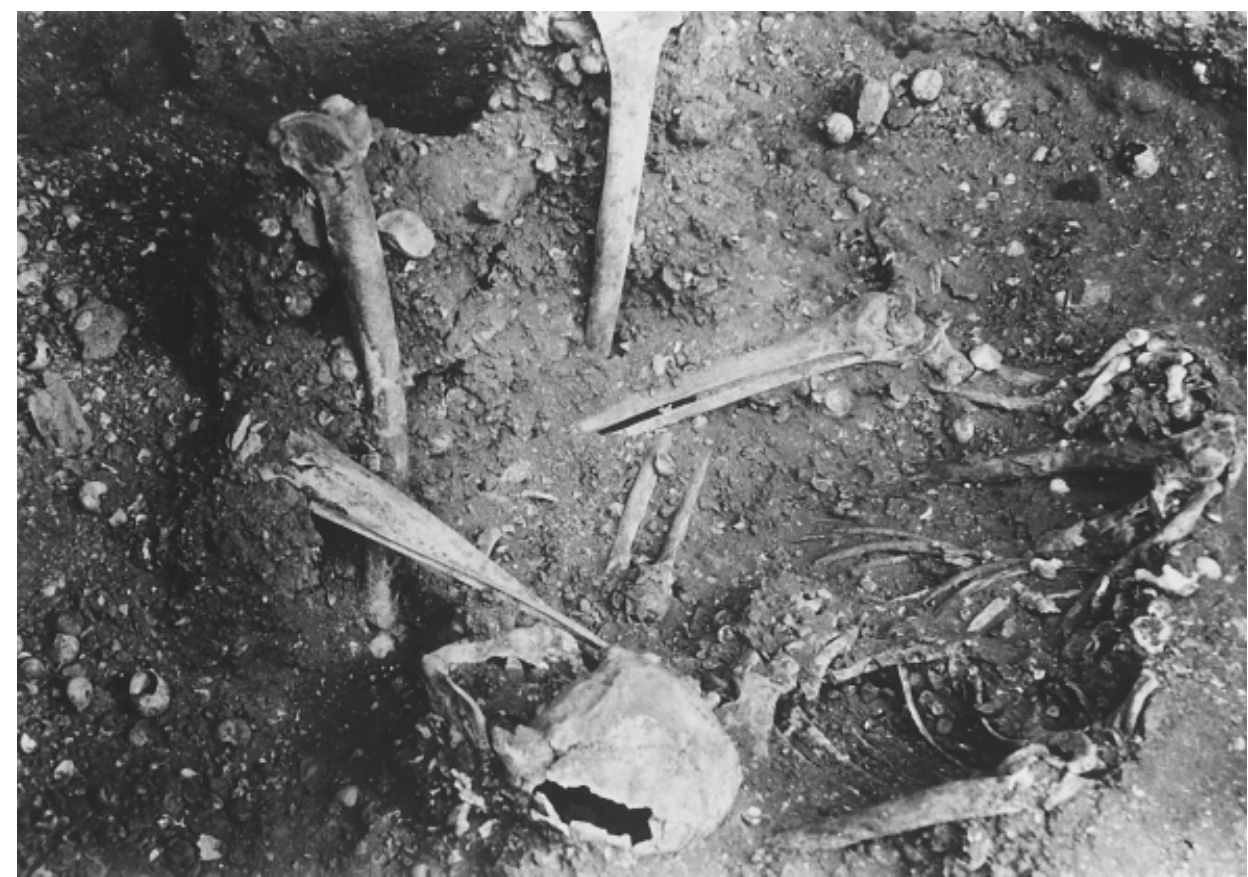

Figure 5. Skeleton 3A-5 (negative 5236: Department of Anthropology, University of Minnesota, Minneapolis): 'Position, with head of vertebral column to W. Pelvis below level of head so that spine had great inclination towards pelvis. Legs half flexed with distal femora upright' (Wilford, unpublished field notes and diary). The skull, lower legs and left forearm are clearly out of place.

occipital pointing up. It was specifically mentioned in the field notes that the skeleton was 'in a rather poor state of preservation but well in place except for the skull and the left forearm'. This individual was buried in the Below Floor level in association with some ochre.

Skeleton $3 A-6$, an adult identified as probably male, was found beneath an unbroken floor level in a layer of well-packed black dirt and shell, with some red ochre. This is the most incomplete individual, in a poor state of preservation and found in a completely mixed up position - The head, both arms and both legs were missing, though all hands and feet were present. The spinal column was divided into two parts which met each other at an acute angle.' Only for this individual did Wilford add a very schematic drawing to the field notes.

Skeleton 3A-7, also an adult male, was buried in the shell in the Middle Level and the dirt layer above it was unbroken-'The few inches above the skeleton was dirt instead of shell.' The skull, as well as both tibiae and fibulae were missing. The axis ${ }^{1}$ was found with the rest of the vertebral column and was stained with red ochre.
More ochre was found in association with the burial.

Once the skeletons were exposed, photographs were taken ${ }^{2}$. The bones were friable, and prior to lifting they were treated with shellac. They were then numbered and left to dry before packing for transportation to Minnesota. The collection which was transferred to the University of Alberta consists of the remains of seven individuals (labelled $3 \mathrm{~A}-1$ to $3 \mathrm{~A}-8$; 3A-4, the presumably intrusive skeleton, was not included).

\section{Study of the cutmarks}

In 1994, CMH discovered the existence of the cutmarks during a detailed examination of the bones, while undertaking preliminary cataloguing and measurement. All bones with 'possible' cutmarks were then studied with a hand lens $(10 \times, 20 \times)$, and a binocular microscope (up to $25 \times)$.

Many of the marks were filled with dirt and covered with shellac which had to be removed 
Table 1. Summary of the results

\begin{tabular}{|c|c|c|c|c|c|c|c|}
\hline & $3 A-1$ & $3 A-2$ & $3 A-5$ & $3 A-6$ & $3 A-7$ & $3 A-3$ & $3 A-8$ \\
\hline Sex & Female & Female (?) & Male & Male (?) & Male & $\begin{array}{l}\text { Subadult } \\
\text { (female?) }\end{array}$ & Infant \\
\hline Bones missing & Axis & $\begin{array}{l}\text { I }+r \text { Humerus } \\
\text { I Radius } \\
\text { I Ulna } \\
\text { I Hand } \\
\text { I }+r \text { Femur } \\
\text { I }+r \text { Tibia } \\
\text { I }+r \text { Fibula } \\
\text { I }+r \text { Patellae } \\
\text { I } r \text { Foot }\end{array}$ & & $\begin{array}{l}\text { Cranium } \\
\text { Atlas } \\
\text { I+r Humerus } \\
\text { I+r Radius } \\
\text { I+r Ulna } \\
\text { I+r Femur } \\
\text { I+r Tibia } \\
\text { I+r Fibula }\end{array}$ & $\begin{array}{l}\text { Cranium } \\
\text { Atlas } \\
\text { I+r Tibia } \\
\text { I+r Fibula } \\
\text { I Patella }\end{array}$ & & Cranium \\
\hline $\begin{array}{l}\text { Bones with } \\
\text { cutmarks }\end{array}$ & $\begin{array}{l}\text { Mandible } \\
\text { Distal } r \text { humerus } \\
\text { I Tibia }\end{array}$ & $\begin{array}{l}\text { Atlas } \\
\text { Axis }\end{array}$ & $\begin{array}{l}\text { Mandible } \\
\text { Atlas } \\
\text { I+r Distal humerus } \\
\text { Prox } r \text { ulna }\end{array}$ & $\begin{array}{l}\text { Axis } \\
\text { I+r Scapula } \\
\text { Sternum } \\
\text { Ribs } \\
\text { Thoracic vertebra }\end{array}$ & $\begin{array}{l}\text { I+r Clavicle } \\
\text { I+r Scapula } \\
\text { sternum } \\
\text { Ribs } \\
\text { Lumbar vertebra }\end{array}$ & & \\
\hline $\begin{array}{l}\text { Deposition } \\
\text { anomalies }\end{array}$ & $\begin{array}{l}\text { Left tibia and fibula reversed; } \\
\text { skull + mandible to right of } \\
\text { body }\end{array}$ & & $\begin{array}{l}\text { Skull + mandible to left of } \\
\text { body; left forearm removed } \\
\text { from left humerus }\end{array}$ & $\begin{array}{l}\text { Vertebral column } \\
\text { angled }\end{array}$ & $\begin{array}{l}\text { Pelvis } 1 \mathrm{ft} \mathrm{NW} \text { of } \\
\text { spinal column; } \\
\text { some lumbar } \\
\text { vertbrae with pelvis }\end{array}$ & & \\
\hline
\end{tabular}

For each individual the bones with cutmarks, missing bones, and deposition anomalies, are indicated. $I=$ left, $r=$ right. 
Table 2. Description and anatomical location of all the cutmarks found on the bones of the adult individuals.

\begin{tabular}{|c|c|c|}
\hline Skeletal element & Individual & Description of the marks \\
\hline \multirow[t]{2}{*}{ Mandible } & $3 A-1$ & R: ramus, near gonial angle; 4 incisions each ca. $2 \mathrm{~mm}$ long, narrow and shallow \\
\hline & $3 A-5$ & $\begin{array}{l}\text { R: ramus, in between gonial angle and caput (= damaged); several parallel incisions, one } \\
\text { relatively deep, } 2 \text { of ca. } 10 \mathrm{~mm} \text { long curving around on external surface (fossa) }\end{array}$ \\
\hline \multirow[t]{2}{*}{ Atlas } & $3 A-2$ & $L$ and $R$ arc (inferior), on left side continuing above the inferior articular facet \\
\hline & $3 A-5$ & L: arc (inferior) on transverse process; ca. 8 incisions, $2-5 \mathrm{~mm}$ long, 1 deep \\
\hline \multirow[t]{2}{*}{ Axis } & $3 A-2$ & Across dens $2-3$ incisions; top of dens removed \\
\hline & $3 A-6$ & $\begin{array}{l}\text { On corpus; } 2 \text { incisions crossing each other, ca. } 8 \mathrm{~mm} \text {, relatively deep; } 2 \text { more shallow } \\
\text { marks, ca. } 4 \mathrm{~mm} \text { long above these } 4-5 \text { more superficial, ca. } 10 \mathrm{~mm} \text { long marks below } \\
\text { right superior articular facet }\end{array}$ \\
\hline \multirow[t]{2}{*}{ Other vertebrae } & $3 A-6$ & One thoracic vertebra; several incisions lengthwise following curvature of body \\
\hline & $3 A-7$ & One lumbar vertebra; several incisions lengthwise following curvature of body \\
\hline \multirow[t]{2}{*}{ Clavicle } & $3 A-7$ & R: several incisions on anterior acromial end, relatively shallow \\
\hline & & L: one very deep incision, ca. $20 \mathrm{~mm}$ long on sternal end (dorsal surface) \\
\hline \multirow{3}{*}{ Scapula } & $3 A-6$ & R: acromion; 5 medium deep incisions \\
\hline & & L: acromion; one long incision ca. 17 mm (in 2 parts), several deep incisions \\
\hline & $3 A-7$ & $\begin{array}{l}\text { R: } 3 \text { incisions on spine, } 2 \text { relatively deep; } 2 \text { incisions on superior margin } \\
\text { L: } 2-3 \text { incisions on acromion }\end{array}$ \\
\hline \multirow[t]{2}{*}{ Sternum } & $3 A-6$ & Corpus: left side, 2 deep incisions, ca. 3 mm long \\
\hline & $3 A-7$ & Corpus: left, ventral side one incision \\
\hline \multirow[t]{3}{*}{ Ribs } & $3 A-6$ & $\begin{array}{l}\text { Both } R \text { and } L \text {, some on collum behind tuberculum, other marks on corpus perpendicular } \\
\text { to rib's axis; mostly on external surface, one on internal surface near sternal end }\end{array}$ \\
\hline & $3 A-7$ & $\mathrm{R}$ : one rib, incisions perpendicular to axis of rib \\
\hline & & L: at least 7 ribs with incisions on corpus \\
\hline \multirow[t]{3}{*}{ Humerus } & $3 A-1$ & $\begin{array}{l}\text { R: } 4 \text { incisions just above medial epicondyl; } 6-10 \mathrm{~mm} \text { long, shallow, narrow; several } \\
\text { incisions just above lateral epicondyl, one relatively deep }\end{array}$ \\
\hline & $3 A-5$ & R: one incision above lateral condyl; 4 mm long, medium depth \\
\hline & & $\begin{array}{l}\mathrm{L} \text { : several incisions on lateral condyl (ventral/lateral side), } 2 \text { deep parallel incisions, ca. } 10 \\
\mathrm{~mm} \text { long on dorsal/lateral side }\end{array}$ \\
\hline Ulna & $3 A-5$ & $\begin{array}{l}\text { R: } 2 \text { parallel incisions ( } 2 \text { and } 4 \mathrm{~mm} \text { long) medially between incisura trochlearis and } \\
\text { coronoid process; possible cut ca. } 2 \mathrm{~cm} \text { above those }\end{array}$ \\
\hline Tibia & $3 A-1$ & L: medial condyl, ventral side; 2 cuts ca. 25 mm long, relatively deep \\
\hline
\end{tabular}

prior to photography and SEM-analysis (Shipman, 1981; Rose, 1983), although for some specimens photomicrographs were made (at $6 \times, 12 \times$, or $25 \times)$ prior to cleaning. Removal of shellac was carried out with alcohol (90\% methyl alcohol, 5\% ethyl alcohol, 5\% propyl alcohol), soft brushes and Q-tips. Another technique was to leave the bones overnight between tissues soaked in alcohol in a sealed plastic bag ${ }^{3}$. Dirt was removed using an ultrasonic cleaner and deionized water.

Two specimens, showing different types of cuts, were selected for SEM analysis. Because of the restricted size of the SEM specimen chamber, epoxy replicas were made of a rib (3A-7) with relatively superficial marks and an atlas (3A-5) with very deep cuts. The mould was prepared from silicone rubber 3110 RTV (Dow Corning ${ }^{\circledR}$ ) and catalyst $S$ (Dow Corning ${ }^{\circledR}$ ), and the cast was made with epoxy resin (electrical resin).

The casts were examined with an Hitachi S-4100 Scanning Electron Microscope at magni- fications ranging from $20-200 \times$. Because of the low accelerating voltage used $(2.0 \mathrm{kV})$ it was not necessary to coat the specimens with gold or palladium.

Most of the striations observed on the bones from Site 12 have been found to be authentic cutmarks. In almost every instance we have considered, and eliminated, all other possibilities including modern tool marks, root marks, tooth marks, vascular grooves and factors from the burial environment such as scratches due to agents in the sediment (Shipman \& Rose, 1984). Given the extremely friable state of the material it would not have been possible to produce such deep and clearly demarcated cuts, as can be observed on some specimens, with a modern tool. Post-excavation, superficial scratches on some of the bones exposed a light-coloured fresh surface-in marked contrast to the cutmarks which are characterized by a weathered appearance and are often filled with dirt. Furthermore, on one vertebra (Figure 17) several incisions can 


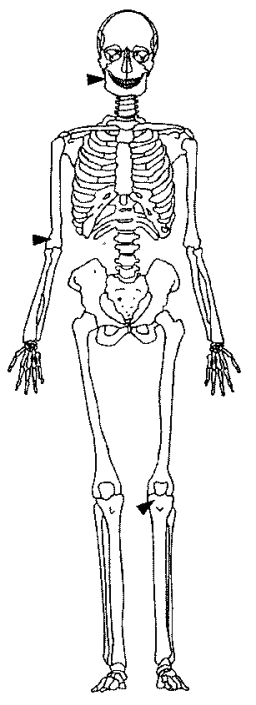

$3 \mathrm{~A}-1$

female

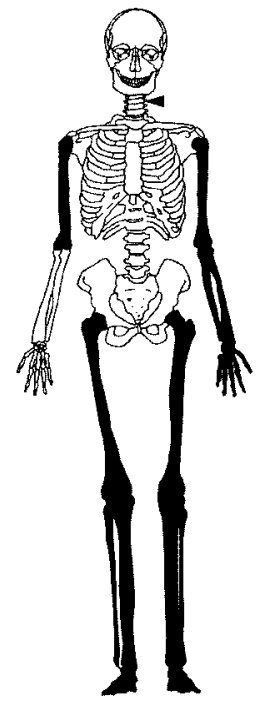

$3 \mathrm{~A}-2$ female (?)

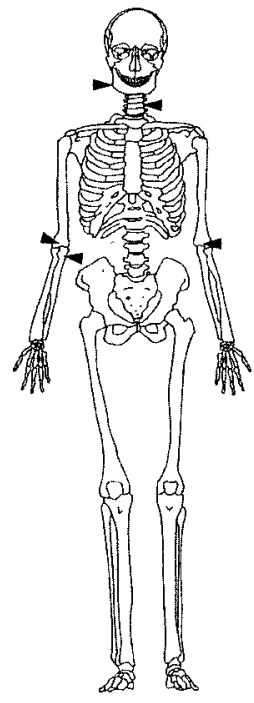

$3 \mathrm{~A}-5$ male

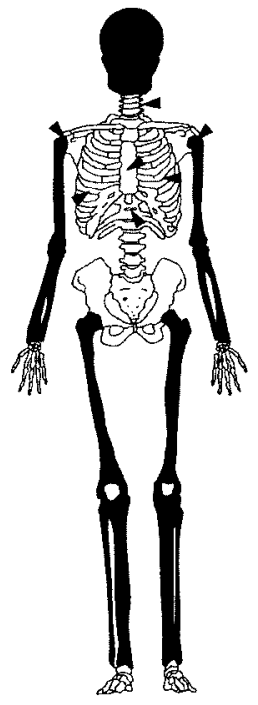

$3 \mathrm{~A}-6$ male (?)

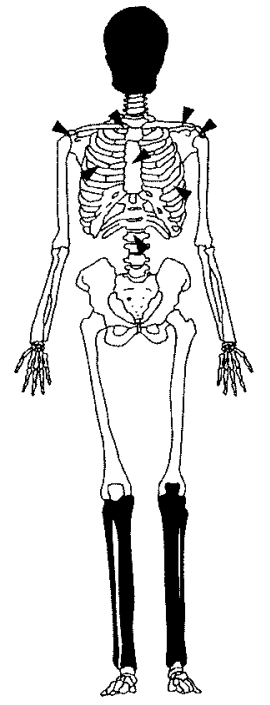

$3 \mathrm{~A}-7$ male

Figure 6. Overview of the general anatomical placement of the cutmarks (arrows) and missing skeletal elements (in black) for each of the individuals.

be seen which are continuous across a postmortem fracture, confirming the antiquity of the marks.

\section{RESULTS AND DISCUSSION}

\section{The cutmarks}

Table 1 summarizes the findings regarding the cutmarks and deposition anomalies for each of the individuals. A more detailed description of the cutmarks is presented in Table 2 and the general anatomical location of the cutmarks is shown in Figure 6. From this figure it is clear that each individual was treated in a different way, although there is a general tendency for the cutmarks to be concentrated in the cervical region and around joints, suggesting decapitation and (partial) dismemberment. In addition, skeletons 3A-6 and 3A-7 show marks in different areas of the thorax. The cutmarks are more fully discussed below. The pattern of missing skeletal elements is also shown in Figure 6, which very strongly suggests intentional removal of skulls and long bones.

\section{Decapitation}

The crania from individuals $3 \mathrm{~A}-6$ and $3 \mathrm{~A}-7$ are missing, while the skulls and mandibles for individuals $3 \mathrm{~A}-1$ and $3 \mathrm{~A}-5$ were found to the side of the body, indicating that there was a special significance to skulls. Because separation of the skull with the atlas and some limbs is described as generally occurring relatively early during natural disarticulation (Haglund, 1991), the cutmarks associated with exactly these skeletal elements indicate that the skulls and long bones were obtained shortly after death.

The posterior location of the marks on the atlas of $3 \mathrm{~A}-2$ and $3 \mathrm{~A}-5$ (Figures 7-9), and the anterior location of the marks on the axis of $3 \mathrm{~A}-2$ and 3A-6 (Figures 10 and 11) indicate that severing of the muscles and ligaments to separate the skull from the vertebral column was done from both sides by drawing the knife across the tissues repeatedly, leaving several marks on the bone. It is possible that, while the ligaments around these vertebrae were cut, accidental marks were made on the ramus of the mandible.

For Site 12, all the cutmarks associated with decapitation have been observed on $C_{1}$ and $C_{2}$ and seem to have been made with a sharp tool. 


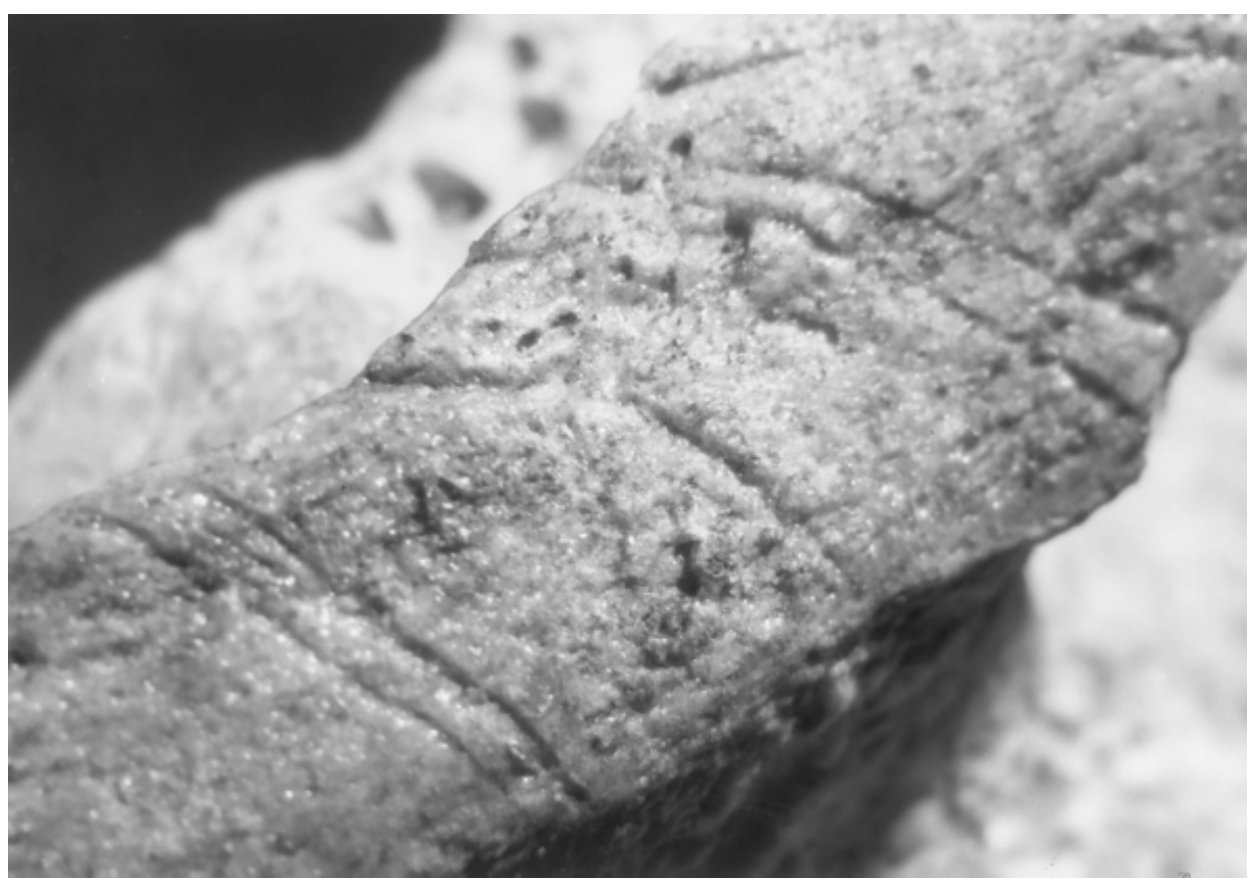

Figure 7. Photomicrograph $(6 \times)$ of the atlas of skeleton $3 \mathrm{~A}-2$ prior to cleaning, showing characteristic double incisions on the right inferior arch.

The atlas of individual 3A-2 (Figure 7) shows sets of parallel lines, corresponding to what White (1986) refers to as the 'dual track morphology', resulting from the use of burins.

Bush \& Stirland (1991), in a study of RomanoBritish decapitation burials from Cirencester and Ashton, report osteological evidence of decapitation in the $\mathrm{C} 3-\mathrm{C} 7$ region for 9 of 12 individuals, and cuts on $\mathrm{C} 1$ and/or C2 for only 4 of 12 individuals. These authors observe that ' $[\mathrm{i}] \mathrm{n}$ the cases of decapitation at the C1-C2 level, it may well be that this was a post-mortem event, given the difficulties of beheading a living individual at this level.' This appears to be in agreement with our findings. The association of a number of cutmarks with ligaments seems to suggest that they were made after a period of decomposition although the green bone response found on some of the bones (including the atlas from 3A-5-Figures 8 and 9) indicates that at least some of the cutmarks were made when the bones were still wet. These observations can be explained in two ways: (1) different cutmarks were made at different times after death, or (2) the environmental conditions were such that decomposition occurred relatively quickly, so that the cutmarks were made when the soft tissues had already disappeared to some extent, but the bone had not yet dried out.

\section{Dismemberment}

The scapulae of skeletons 3A-6 and 3A-7 show incisions on the acromion and spine (Figure 12). The marks on the acromion are the result of severing the ligaments that hold the humerus and scapula together, indicating that the objective was to separate the arm from the rest of the body. The cutmarks on the spine (3A-7) are best explained by a procedure which involved initial cutting of the deltoid at the deltoid tuberosity of the humerus, reflecting the muscle back over the shoulder and then gradually separating it from the underlying spine of the scapula, leaving small nicks on the bone. Based on the location of the cutmarks on the spine, which is quite medial, it appears that the deltoid was a relatively large muscle in this individual. This is supported by the size of the deltoid tuberosity on the humerus; no cutmarks have been observed in this area.

It is interesting to note that apparently the arms were separated from the body by severing 


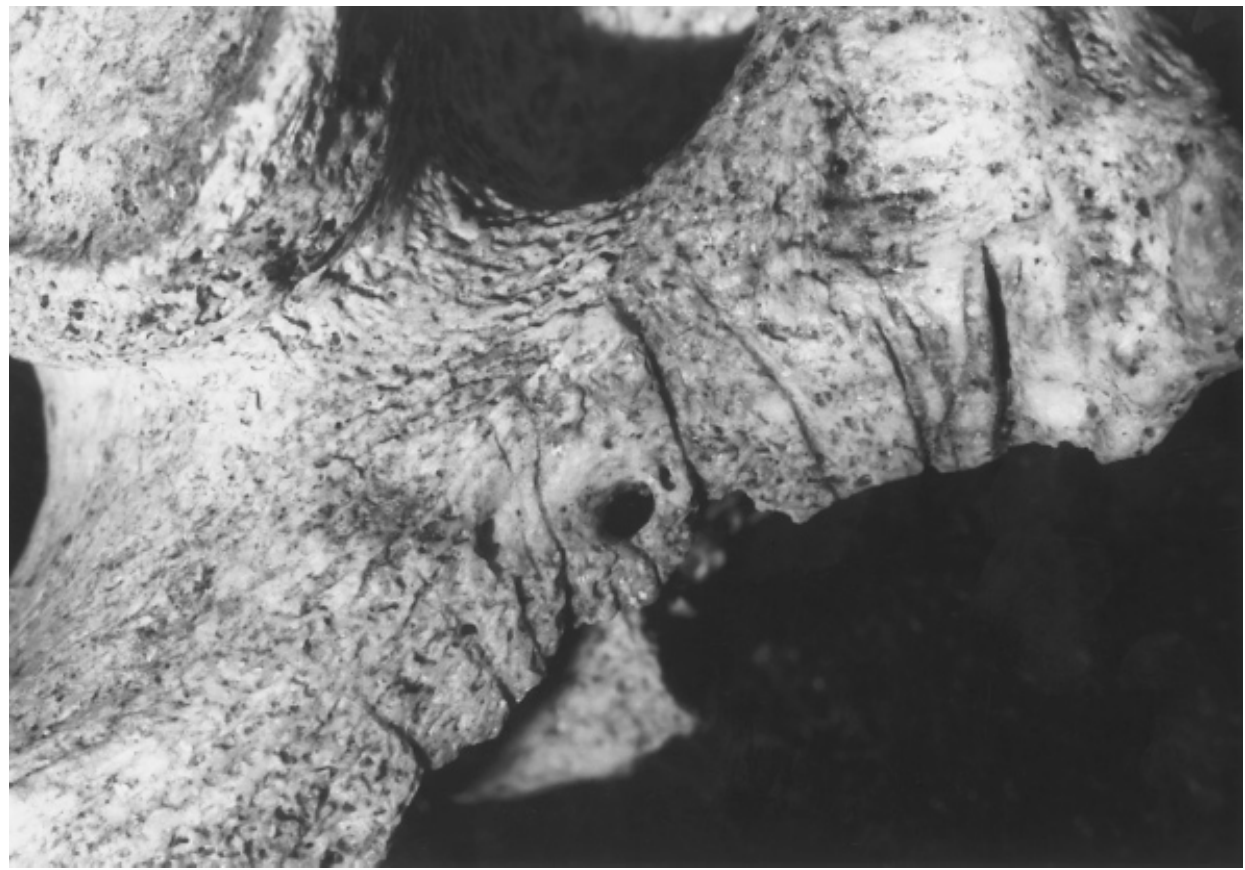

Figure 8. The atlas of skeleton 3A-5. Several incisions (2-5 mm long), some quite deep, on the inferior aspect of the left transverse process.

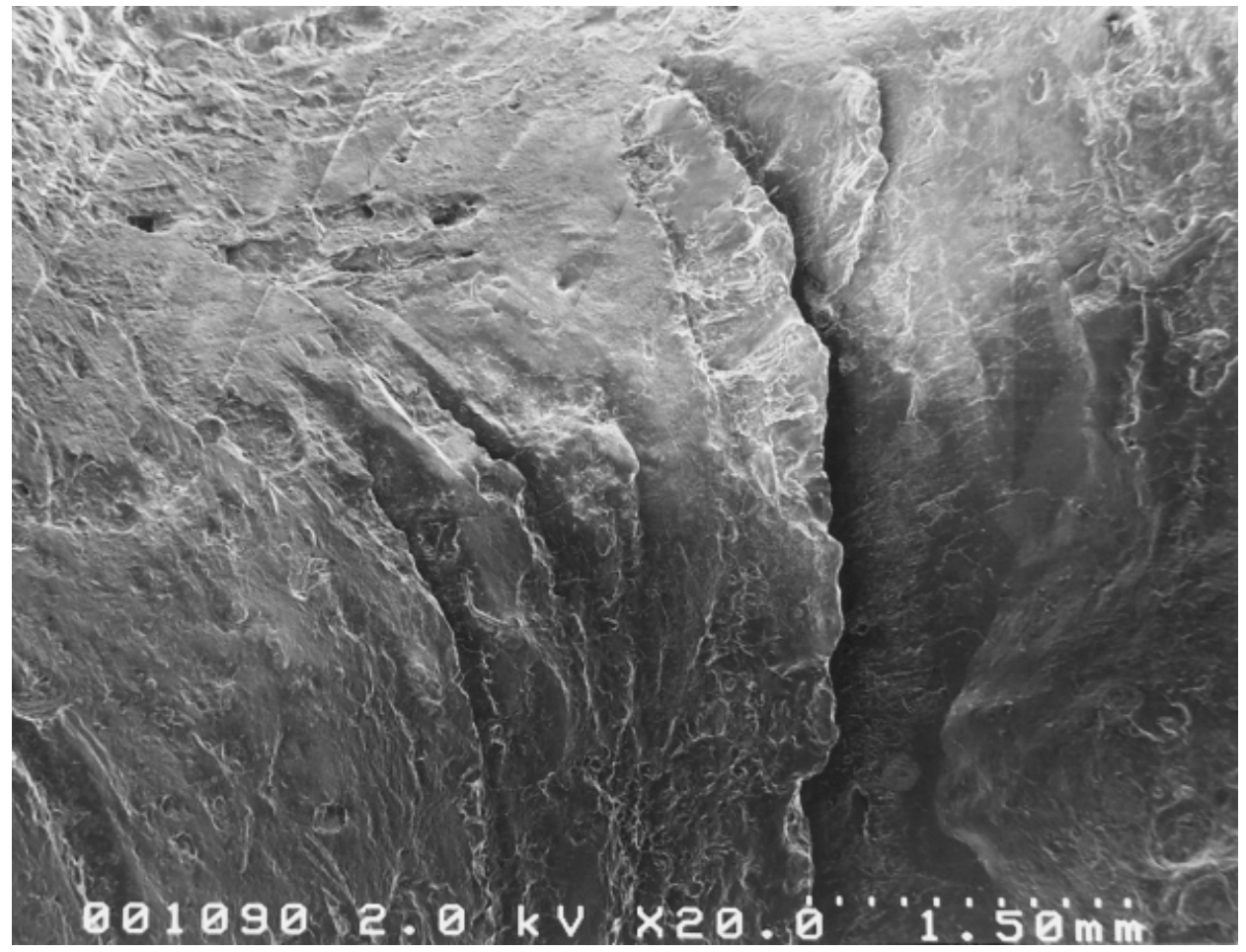

Figure 9. Scanning micrograph of the cutmarks on the atlas of $3 A-5$, showing the green bone response. The marks shown correspond to the marks on the right in Figure 8. 
the deltoid muscle and the ligaments that keep the humerus and scapula together. An easier way of separating the arm from the body would be to separate both the arm and the scapula, by severing the muscles around the scapula. This has been reported by Jelinek (1993) for two individuals from a Bronze Age site in Moravia (Czech Republic). In both cases, the entire arm including the scapula was missing.

The cutmarks on the extremities themselves are limited to the humerus (3A-1, 3A-5-Figure 13), ulna (3A-5) and tibia (3A-1-Figure 14). On the bones of the arm, cutmarks were only found in the area of the elbow joint. Marks on the medial and lateral epicondyles of the humerus would result from cutting both muscle tissue (extensor group on lateral side and flexor group on medial side) and ligaments (ulnar collateral on medial side and radial collateral on lateral side) in these areas. The cutmarks on the ulna (3A-5) can be interpreted as resulting from the same action. Of the five adult skeletons, $3 \mathrm{~A}-1$ is the only one which shows cutmarks on the lower extremity. These marks are most easily explained as resulting from cutting the anterior cruciate in a medial to lateral direction, after the patella and the patellar ligament had been reflected back. The collateral ligaments had probably already disappeared as a result of either human action or decomposition.

Although for individual 3A-1, cutmarks have been observed on both the elbow and knee joints, none of the long bones are missing. This

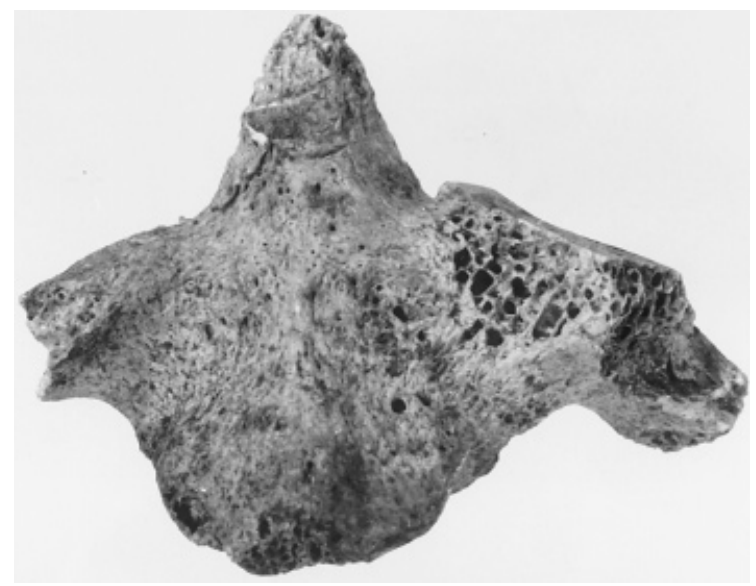

Figure 10. Axis of $3 \mathrm{~A}-2$ showing incisions across the articular facet of the dens. indicates that dismemberment was deemed necessary or appropriate for some reason prior to burial. Nevertheless the extremities were placed in the grave with the rest of the body.

The marks on the extremities all occur on the epiphyses, and none have been observed along the shaft. This is in contrast to the finding of other authors (Jelinek, 1993), who have reported cutmarks along the shafts of the long bones, in addition to those around the joint region. Numerous cutmarks on the shafts have been interpreted by some as evidence of extensive cleaning of the bones (Ullrich, 1982; Russell, 1987; Jelinek, 1993); however, this has been disputed by others (Villa, 1992).

\section{Marks on the thorax}

The marks on the thorax of skeletons $3 \mathrm{~A}-6$ and 3A-7 are more enigmatic. The cutmarks observed on various ribs of these individuals appear to be associated with the removal of the muscle sheets around the thorax, such as the oblique muscles and serratus anterior. Since the thorax tends to disintegrate relatively quickly, these cutmarks were probably made shortly after death. One set of incisions across the corpus of a left rib is shown in Figure 15A,B and illustrates the characteristic curvature of the marks as the blade was drawn across the bone in a vertical direction (cranial-caudal). This is most consistent with a skinning action, working from front to back, pulling away the tissue while cutting and leaving several marks on the bone. The small incisions on the sternum could be interpreted as chattercuts related to removal of the muscular sheet around the thorax.

The right clavicle of skeleton 3A-7 shows a deep incision with no signs of healing on the inferior aspect of the sternal end (Figure 16). The green bone response shows the incision was made perimortem. This is the only cutmark that could conceivably have been causally related to death. The cutmarks on the sternal and acromial ends of the right and left clavicles are associated with severing of the sternocleidomastoid and possibly the deltoid or rotator cuff.

The incisions on an upper thoracic vertebra of skeleton 3A-6, and on an upper lumbar vertebra of skeleton 3A-7 (Figure 17) could have resulted from cutting of the anterior longi- 


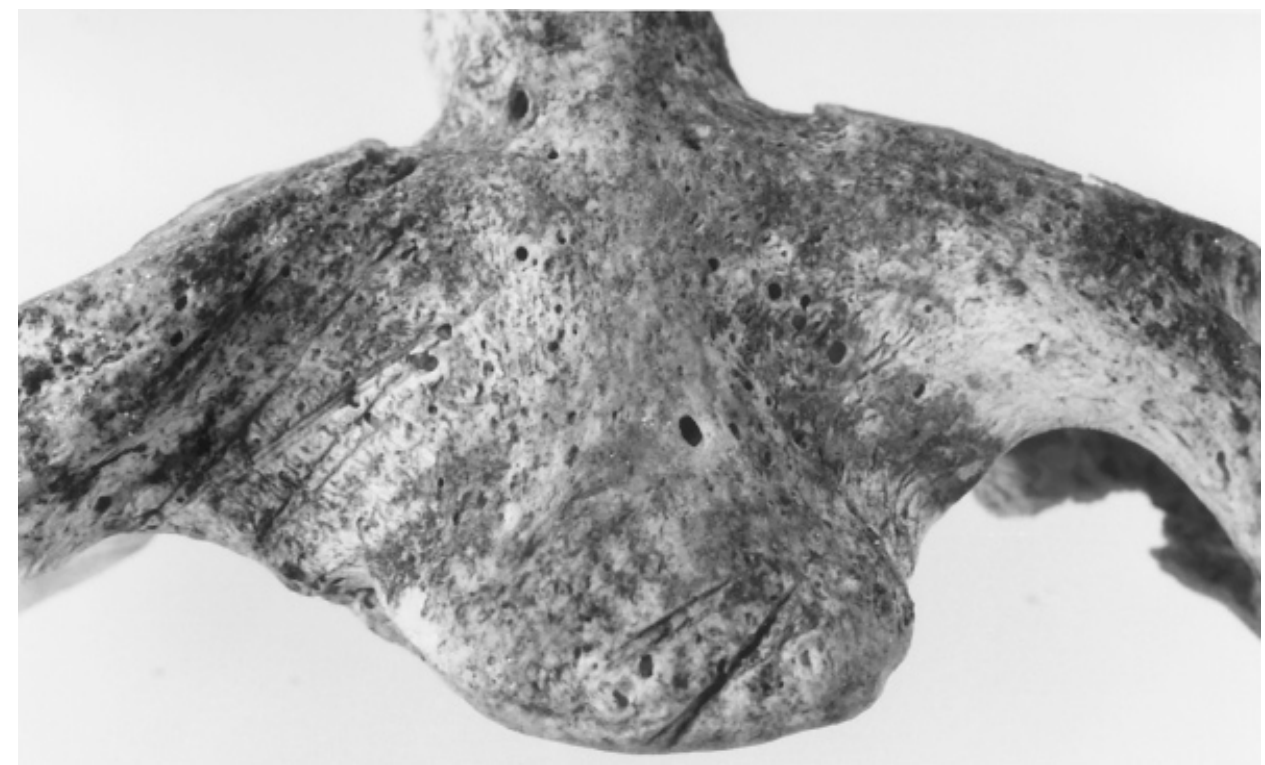

Figure 11. Axis of 3A-6. There are several relatively deep incisions on the corpus and a number of more superficial marks (some doubled) below the right articular facet.

tudinal ligament with the intention of taking the vertebral column apart. This may explain why the vertebral column of skeleton $3 \mathrm{~A}-6$ was found in two segments, meeting at an acute angle. For individual $3 \mathrm{~A}-7$, the pelvis was found ' $1 \mathrm{ft} \mathrm{NW}$ of spinal column', with 'some lumbar vertebrae with pelvis' (Wilford, unpublished field notes and diary). These marks could also represent secondary damage resulting from removal of the internal organs while accidentally severing the anterior longitudinal ligament. There is a remarkable similarity between the location of the marks on ribs, sternal bodies and thoracic/lumbar vertebrae of Site 12 individuals, and those reported by Jelinek (1993) on the remains of the two Bronze Age individuals from Moravia (Czech Republic), which he interprets as evidence for filetting and evisceration.

The bodies were most likely prepared shortly after death, when some decomposition of soft tissues had already taken place. The preparation involved decapitation, (partial) dismemberment and, in some cases, defleshing of the thorax and possibly removal of the internal organs. At Site 12 , the bones from the dismembered extremities were in some cases found in the grave with the rest of the body. It seems, therefore, likely that these preparation activities were of some practical or ritual significance.

Copyright (C) 1999 John Wiley \& Sons, Ltd.
Huntington \& Metcalf (1979) mention a possible reason for removal of the internal organs: in cases of delayed burial the organs are sometimes removed in order to extend the period of reasonable preservation. For the remains from Site 12, this interpretation offers an interesting avenue of analysis, especially in light of the fact that the practice of delayed, secondary burial has been linked to a nomadic lifestyle. It has been suggested that among nomadic peoples, individuals who died away from camp were defleshed at the place of death and then brought back to the main camp or some other specific site in order to be buried (Byrd \& Monahan, 1995; Kuijt, 1996).

Nomadism and secondary burial: an bypotbetical reconstruction of Capsian mortuary practices

Eight thousand years ago the environment in this region was characterized by open savanna woodland (Lubell, 1984; Vernet, 1995). Capsian groups were hunter-gatherers, and localities such as Site 12 were probably occupied on a seasonal basis (Lubell et al., 1976) and rarely, if ever, in winter. Escargotières vary in size, and some of the larger sites may represent main camps which were used in conjunction with a 


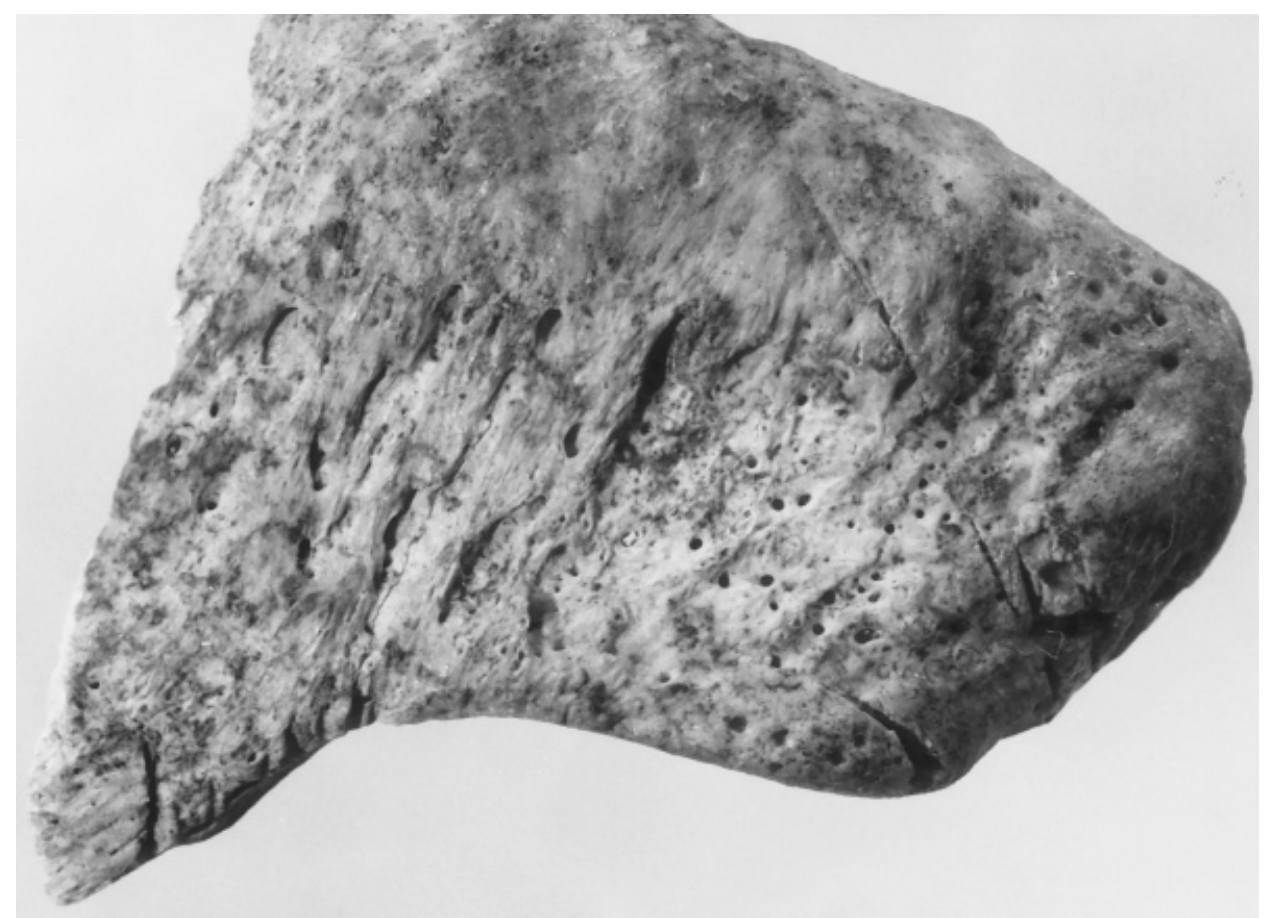

Figure 12. The acromion of the left scapula of 3A-6, showing one long (ca. $17 \mathrm{~mm}$ ) incision, and several shorter, deeper incisions along the margin.

number of smaller camps. There is a tendency for larger sites to be associated with more numerous human remains, a correlation which cannot always be explained by a longer habitation period of the site. This points to the possibility that certain sites had a special significance and were preferred as burial sites, of. the nomadism $=$ secondary burial hypothesis (Kuijt, 1996).

With a pattern of seasonal mobility and the use of satellite camps, the death of a group member away from the main camp may not have been an uncommon event. Depending on the circumstances of death and the distance from the main camp, varying times may have elapsed between death and burial for each of the individuals, and this may account for the variability in completeness of the recovered remains. While awaiting transport of the deceased to the final burial site, members of the group carried out some preliminary preparations, such as the removal of internal organs. The location and nature of some cutmarks suggest that the bodies were partly decomposed before preparation, which could mean that the bodies were exposed for some time. The bones show no indication of surface exposure - weathering, for example - for an extended period of time, or until complete skeletonization was obtained. Skeletonization may have been partly promoted by human intervention, as suggested by the defleshing marks on the thorax. Possibly, the intent of all preparation activities was a reduction of the body to facilitate transport.

None of the bones shows unambiguous signs of carnivore or rodent gnawing, indicating that the bodies were inaccessible to scavengers during the period between death and burial. Thus, if exposure was involved, it appears most likely that the bodies were protected, either by wrappings or by being placed on a scaffold.

Once the bodies arrived at Site 12, a formal burial ceremony was conducted, during which red ochre was used to mark certain areas of the body. Pond (1938) discussed the possibility that the association of red ochre with the burials was an artefact of the excavation strategy rather than real: the use of more refined techniques and tools during the excavation of skeletal remains could have selectively revealed red ochre 


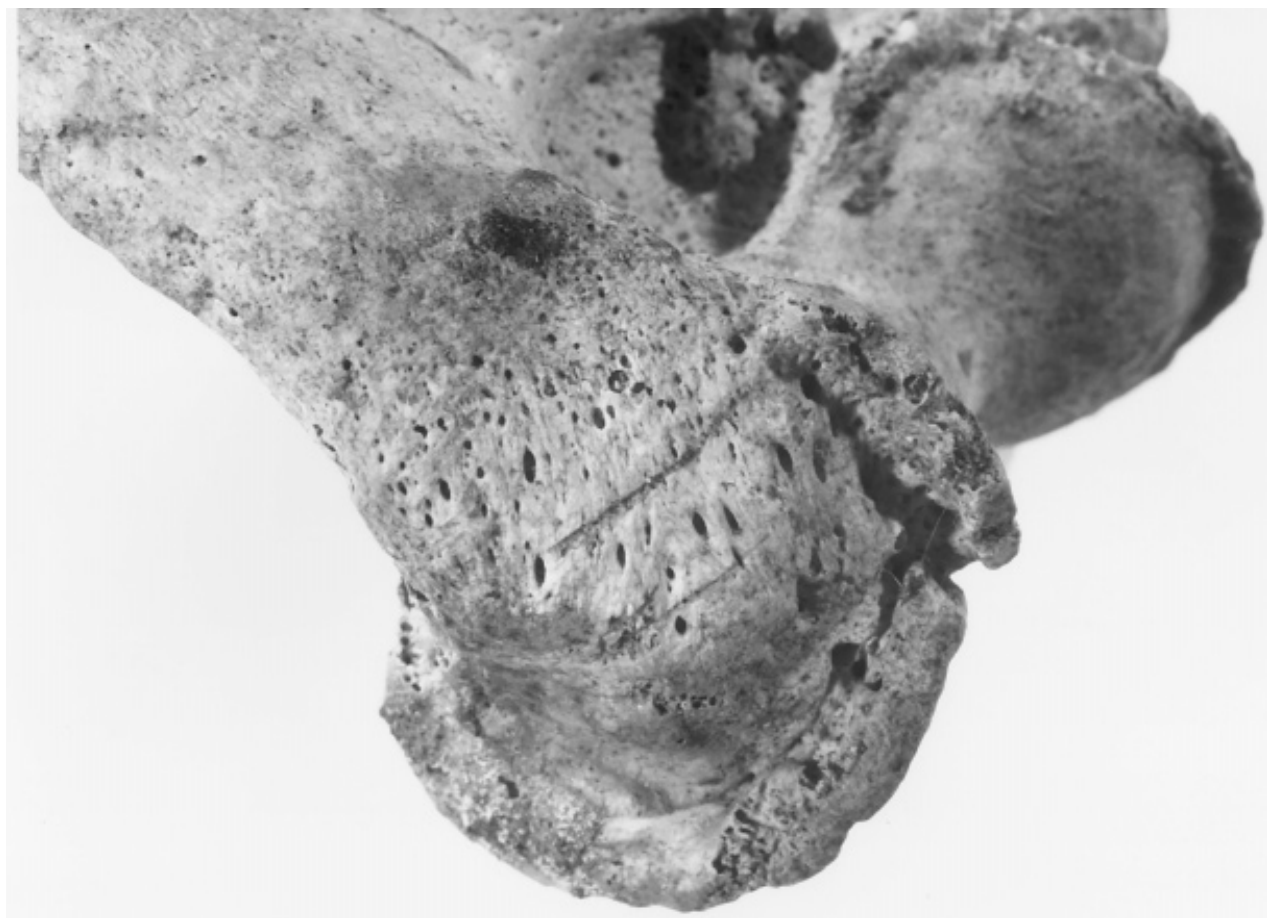

Figure 13. Lateral condyl of the left humerus of $3 \mathrm{~A}-5$, showing two ca. $10 \mathrm{~mm}$ long incisions on the dorsal/lateral side. Note the arthritic bone growth.

in those areas, whereas it may have been present throughout the deposits, but would not have been noted, while doing the crude shovelling. An association between burials and ochre in the Capsian, and ochre coatings on implements, has long been known (Gobert, 1950; Camps-Fabrer,

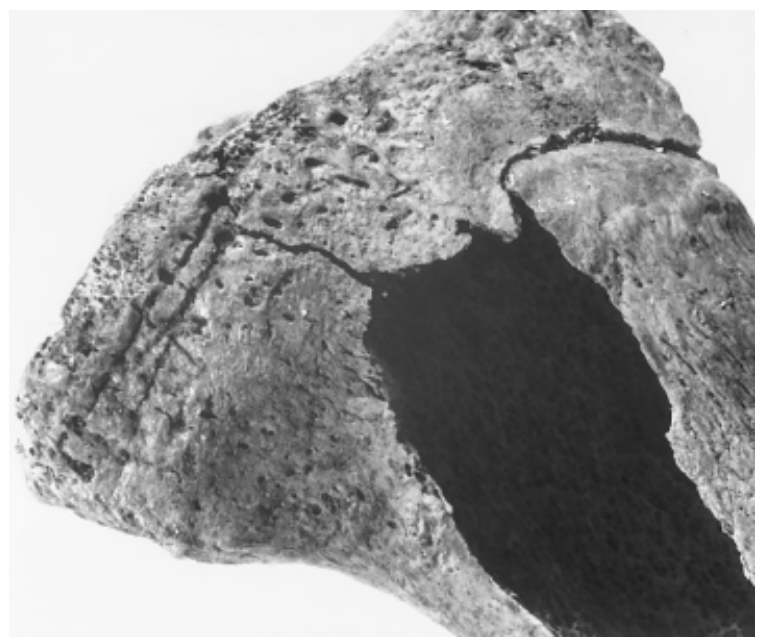

Figure 14. The anterior medial condyl of the left tibia of 3A-1. The incisions are ca. $25 \mathrm{~mm}$ long.
1960, 1966; Inizan, 1976), and is supported by data from carefully excavated contemporaneous sites such as Medjez II (Camps-Fabrer, 1975), where single inhumations of adults and subadults and infants have been found, often associated with red ochre and other grave goods. Extensive use of ochre has now been demonstrated for the preceding Iberomaurusian as well (Ighilahriz, 1996).

The bodies were placed in different positions, possibly related to state of completeness (parts may have been lost during transportation), or state of disintegration (depending on time elapsed since death). Certain body parts, such as the torso of $3 \mathrm{~A}-1$ and $3 \mathrm{~A}-5$, were found in perfect anatomical relationship, while the extremities were out of place. Cutmarks, in those cases, indicate that these individuals were partially dismembered, but care was taken to place the lower legs and arms in the grave with the rest of the body. Pond (1938) in an attempt to understand the presence of human remains in the escargotières, acknowledged the possibility that in some cases the body was temporarily disposed of at the time of death, in one way or 
another, and that later the bones were collected for burial at the camp site. The burials of Site 12 are clearly not secondary burials of collected bones, but primary inhumations, however.

Figure 6 shows that long bones and skulls were selectively removed. Although it is not possible to state with any certainty what the missing bones were used for, it has long been known that Capsian groups modified human bones either for utilitarian or ritual purposes. The 'trophy skull' found at Faïd Souar II in Algeria in 1954 (Vallois, 1971), which has the appearance of a mask, suggests a ritual purpose for skull removal. This exceptional skull was recovered from what was described as a 'complex burial', and is characterized by the careful removal of the basal region, and a bilateral perforation of the parietals. In addition to these modifications, another remarkable finding was that an artificial tooth was present in the socket of the maxillary right second premolar. A detailed study revealed that it had most likely been inserted post-mortem and had been manufactured out of bone rather than wood. It was hypothesized that it could have been made out of a human phalanx, possibly one of the bones that appeared to be missing from the hand on which the skull was found resting in the grave. Numerous other instances of human bone modification are known from sites such as Columnata, Mechta el Arbi and Bortal Faker (Brahimi, 1972; Camps-Fabrer, 1975), involving crania, mandibles and long bones (Camps-Fabrer, 1960, 1966). One assumes these were collected intentionally as relatively green bone, but the possibility remains that they may have been found long after death and burial. For Site 12 it seems most likely that the skulls were taken prior to

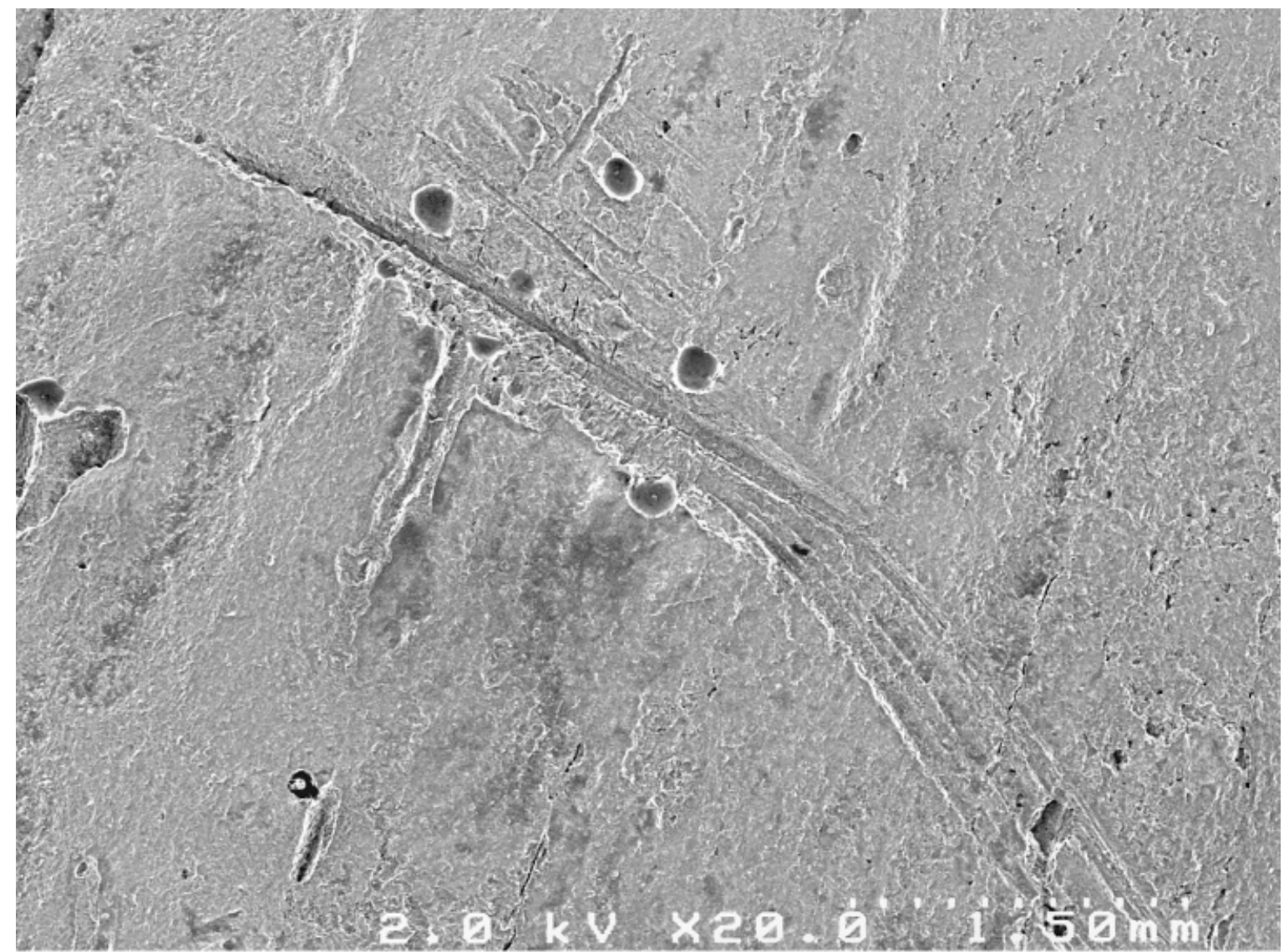

(A)

Figure 15. Scanning micrograph of cutmarks on a left rib of $3 A-7$, showing $(A)$ the characteristic curvature at the end of the incisions $(20 \times)$, and $(B)$ a higher magnification of a doubled mark in the area of the curve $(100 \times)$. 


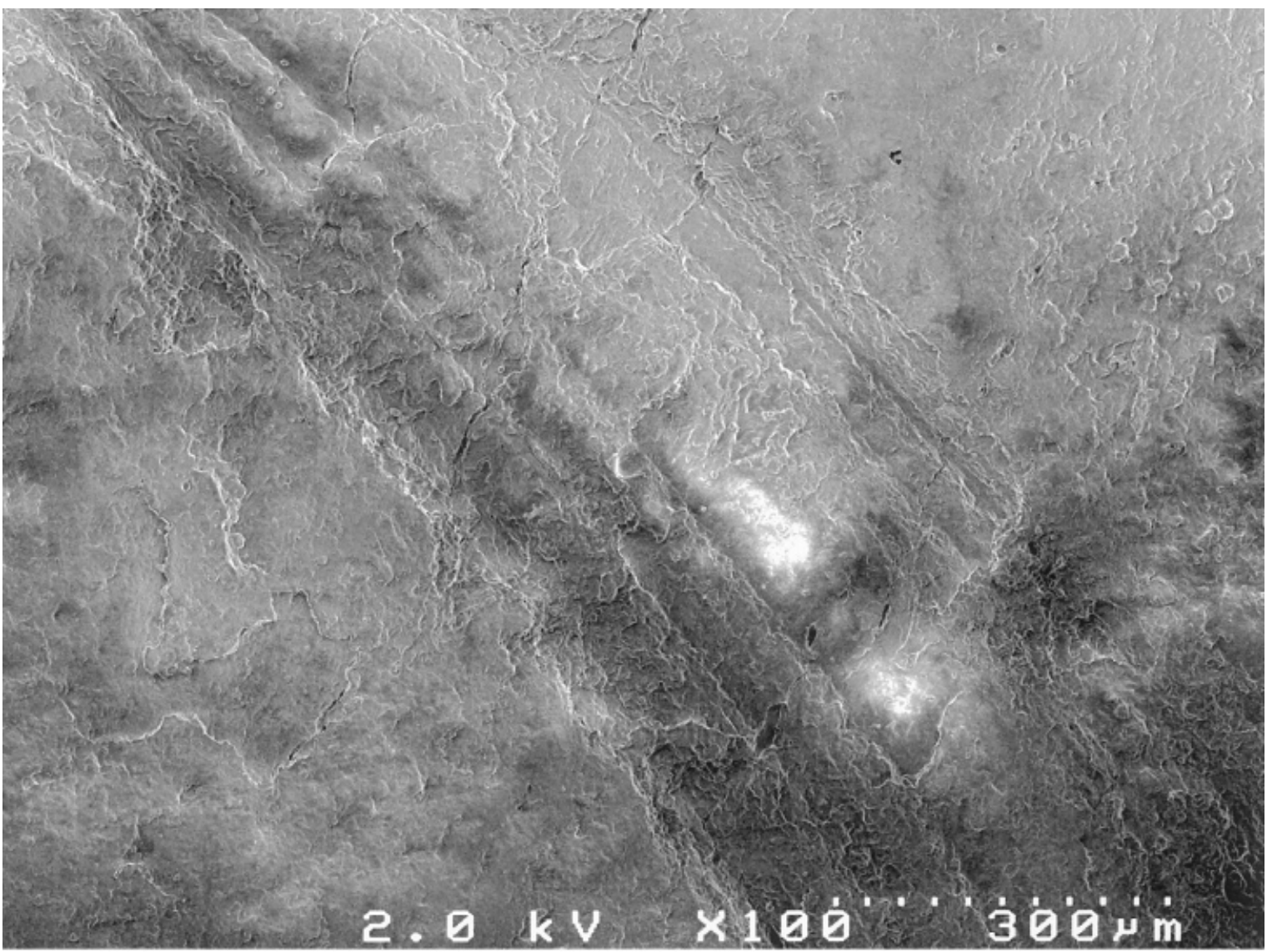

(B)

Figure 15 (Continued)

burial, indicated by the presence of cutmarks on the cervical vertebrae, some of which were evidently made on fresh bone, and the undisturbed layers above the graves of 3A- 6 and 3A-7.

Skull removal, or at least separate burial of crania, is known in the Iberomaurusian (Arambourg, 1934; Hachi, 1996) and has also been found for Late Natufian and PPNA sites in the south-central Levant (Kuijt, 1996). For the Levant, the skulls appear to have been removed after defleshing, since there were no cutmarks associated with the missing skulls. In Early/Late Natufian burials at various sites, the area of the head of the deceased was marked with rock cairns or individual stones (Byrd \& Monahan, 1995), possibly to facilitate retrieval of the skulls later (Kuijt, 1996). For those Maghreb sites at which burials are well documented (e.g., Afalou-bou-Rhummel (Arambourg, 1934; Hachi,
1996), Aïn Misteheyia, Columnata (Cadenat, 1957; Chamla et al., 1970), Medjez II, Taforalt (Ferembach et al., 1962; Roche, 1963)), the grave almost always has some sort of 'structure', often composed of large rocks, which may have had a similar purpose.

\section{Conclusion}

If the individuals found at Site 12 indeed died elsewhere, yet were brought back to be buried at this place, Site 12 may have been one of the more significant locales for these people. Figure 2 indicates an association of skeletons 3A-2, $3 \mathrm{~A}-5,3 \mathrm{~A}-6$ and possibly $3 \mathrm{~A}-1$ with the Below Floor level, while 3A-3, 3A-7 and 3A-8 appear to be younger than that. It is more than likely that the technological transition, dated at about 


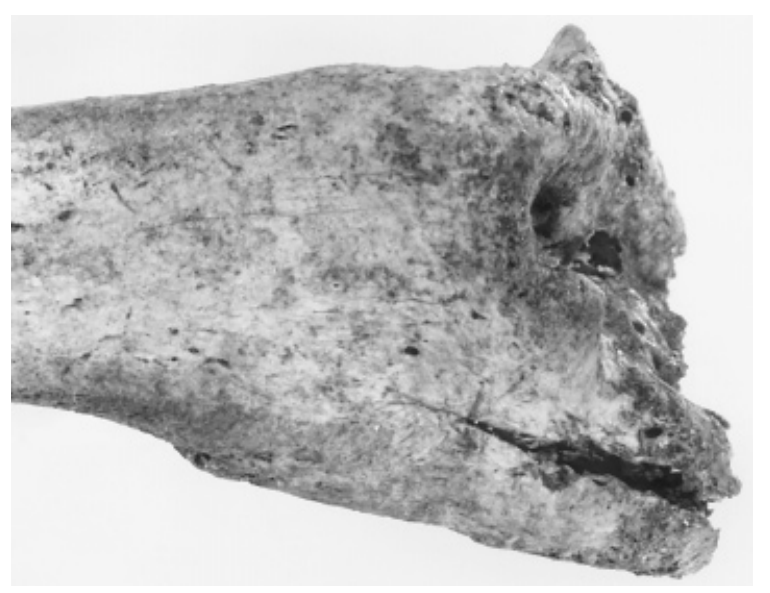

Figure 16. The right clavicle of $3 A-7$. The inferior aspect of the sternal end shows a very deep cut, ca. $20 \mathrm{~mm}$ long.

8000 cal BP (Sheppard \& Lubell, 1990), is represented in the division between the Below Floor level and the overlying deposits. The fact that no clear differences in mortuary treatment are found across this boundary (although the sample size is admittedly small), may indicate that related groups of people returned time after time to this place. This seems to support the observations of Sheppard \& Lubell (1990) and others (Tixier et al., 1976) that the characteristics of the lithic assemblages differ among sites, suggesting an association of distinct groups with particular sites, and that there is continuity in cultural practices between the earlier Iberomaurusian and the Capsian (Hachi, 1996).

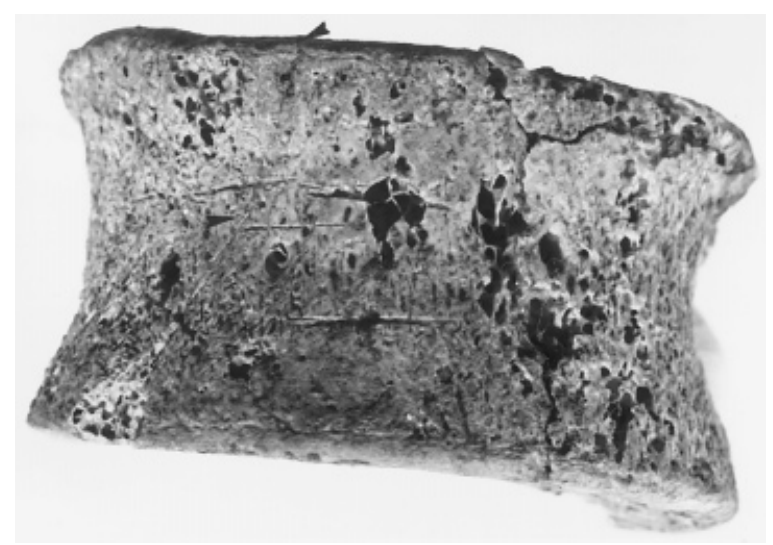

Figure 17. Several cutmarks across the body of a thoracic vertebra of skeleton 3A-7. The arrows indicate a post-mortem fracture crossing one of the cutmarks.
The implications for a reconstruction of Maghreb Holocene social organization and palaeoeconomy are considerable. If, as is the case for other recent and even modern huntergatherers in semi-arid environments (Lourandos, 1997), sense of place, movement between such places, and organization of social, ritual and economic activities to take into account season and locale, were all important variables in scheduling daily and annual activities then our ability to enrich our interpretations of the prehistoric Maghreb are considerably enhanced by the findings reported here.

Although this study is the first to report cutmarks on Holocene human remains from the Maghreb, there is evidence for decapitation and dismemberment at other sites. For example, Aïn Keda yielded many isolated fragments of crania, mandibles, teeth and long bones, and Bayle des Hermens, 1955 concluded that the position of the bones and fragments indicated defleshing and dismemberment prior to burial, after which the burial space was not disturbed again. He refers to similar finds reported by Bardin (1953) for the Neolithic site of Kef-el-Agab in Tunisia. At Dakhlat es-Saâdane (Tixier, 1955) the postcranial remains of one individual were found, together with fragments of bone and flint as well as red ochre, but with no trace of either cranium or mandible. It was concluded that the find represents the inhumation of a decapitated individual. This suggests to us that more human remains from this area, often excavated decades ago, may show similar types of evidence. Re-examination of skeletal collections from major sites such as Afalou-bou-Rhummel (where there are new finds), Columnata, Mechta el-Arbi, Medjez II and Taforalt should now be undertaken.

\section{Acknowledgements}

The late Elden Johnson first brought the Site 12 materials held at the University of Minnesota to the attention of DL and encouraged him to undertake further study. Preliminary work has been done by several students (Cidália Duarte, $\mathrm{Fu}$ Yong, Natalka $\mathrm{Cmoc}$ and $\mathrm{CH}$ ) under the supervision of Mary Jackes. Michael Tarabulski 
(then a student at Beloit) and Lawrence Breitborde (then Chair of Anthropology at Beloit) provided information and facilitated access to archival materials at the Logan Museum, as did Henry Moy (Director of Museums, Beloit). Guy Gibbon (Anthropology, University of Minnesota, Minneapolis) and Nicolette Bromberg (Curator, Visual Materials Archive, State Historical Society of Wisconsin) made available copies of original records in their care. Margo Brunn (Provincial Museum of Alberta, Edmonton) advised on conservation techniques. We thank David Epp (Photographic services, Earth and Atmospheric Sciences, University of Alberta), Deb Komar and Pamela Mayne-Correia (Anthropology, University of Alberta), Christopher Meiklejohn (University of Winnipeg) and Richard Sherburne (Department of Medical Microbiology and Immunology, University of Alberta) for assistance and advice on various aspects of this research.

Alonzo and Dorothy Pond set a standard for Maghreb archaeological research that was not equalled for many years. Their supervision of the 1930 excavations, and their encouragement over many years to DL has contributed to this study which was supported by funding from the Faculty of Arts and the Central Research Fund, University of Alberta, to DL. CH was the recipient of an Izaak Walton Killam Memorial Scholarship while conducting this study and additional financial assistance from Stichting Fonds Doctor Catharine van Tussenbroek is gratefully acknowledged.

\section{Notes}

1. In the field notes, Wilford wrote: 'Atlas vert. present, stained with red ochre'. However, the atlas is missing and the axis is present. This could either mean the atlas has been removed from the collection, or the bone was misidentified in the field.

2. Photographs are only mentioned in the field notes/diaries for the individuals 3A-1, 3A-2 and 3A-5. These photographs were part of the archival collections at Beloit College and the University of Minnesota. For the other individuals photography in the field is not mentioned, nor have any photographs of these individuals been identified among the archival resources.

3. This technique was suggested to us by Margo Brunn (Provincial Museum of Alberta, Edmonton).

\section{References}

Arambourg, C. (1934) Géologie, paléontologie, archéologie. In: Les Grottes Paléolithiques des Beni Segonal (Algérie) (edited by C. Arambourg, M. Boule, H. Vallois and R. Verneau). Paris: Archives de l'Institut de Paléontologie Humaine, Mém. 13, $1-35$.

Bardin, P. (1953) La Grotte du Kef-el-Agab (Tunisie)_Gisement néolithique. Libyca, I: 271308.

Bayle des Hermens, R. de. (1955) L'abri préhistorique de l'Aïn Kéda-Commune de Tiaret, Département d'Oran. Libyca, III: 129-161.

Bennike, P. (1985) Palaeopathology of Danish Skeletons. A Comparative Study of Demography, Disease and Injury. Copenhagen: Akademisk Forlag.

Brahimi, C. (1972) Initiation à la Prébistoire de l'Algérie. Alger: S.N.E.D.

Bunn, H.T. (1981) Archeological evidence for meateating by Plio-Pleistocene hominids from KoobiFora and Olduvai Gorge. Nature, 291: 574-577.

Bush, H. and Stirland, A. (1991) Romano-British decapitation burials: a comparison of osteological evidence and burial ritual from two cemeteries. Antbropologie, XXIX: 205-210.

Byrd, B.F. and Monahan, C.M. (1995) Death, mortuary ritual, and Natufian social structure. Journal of Antbropological Archaeology, 14: 251-287.

Cadenat, P. (1957) Fouilles à Columnata: Campagnes 1956 et 1957: la nécropole. Libyca, 5: 49-81.

Camps, G. and Camps-Fabrer, H. (1972) L'Épipaléolithique récent et le passage au Néolithique dans le nord de l'Afrique. In: Die Anfänge des Neolithikums vom Orient bis Nordeuropa, Teil 7 (edited by J. Lüning). Köln: Böhlau Verlag, 19-59.

Camps-Fabrer, H. (1960) Parures des temps préhistoriques en Afrique du Nord. Libyca, 8: 9-221.

Camps-Fabrer, H. (1966) Matière et Art Mobilier dans la Prébistoire Nord-Africaine et Sabarienne (Mémoire du C.R.A.P.E., No. 5). Paris: Arts et Métiers Graphiques.

Camps-Fabrer, H. (1975) Un gisement Capsien de faciès sétifien Medjez II, El-Eulma (Algérie). Paris: Éditions du Centre National de la Recherche Scientifique.

Chamla, M.-C., Biraben, J.-N. and Dastugue, J. (1970) Les Hommes Epipaleólitbiques de Columnata (Al- 
gérie occidentale): Étude Anthropologique (Mémoire du C.R.A.P.E., No. 15). Paris: Arts et Métiers Graphiques.

Ferembach, D., Dastugue, J. and Poitrat-Targowla, M.-J. (1962) La Nécropole Epipaléolithique de Taforalt (Maroc Oriental): Étude des Squelettes Humains. Rabat: Edita Casablanca.

Gobert, E.G. (1937) Les escargotières: le mot et la chose. Revue Africaine, 81: 639-645.

Gobert, E.G. (1950) Sur un rite capsien du rouge. Bulletin de la Société des Sciences Naturelles de Tunisie, 3: $18-23$.

Hachi, S. (1996) L'Ibéromaurusian, découverte des fouilles d'Afalou (Bédjaîa, Algérie). L'Antbropologie, 100: $55-76$.

Haglund, W.D. (1991) Applications of Taphonomic Models to Forensic Investigations. PhD dissertation, University of Washington.

Huntington, R. and Metcalf, P. (1979) Celebrations of Death-The Antbropology of Mortuary Ritual. Cambridge: Cambridge University Press.

Ighilahriz, F. (1996) L'ocre dans l'industrie lithique de l'Ibéromaurusian d'Afalou-bou-Rhummel (Algérie). L'Anthropologie, 100: 77-87.

Inizan, M.-L. (1976) Outils lithiques Capsiens ocrés. L'Antbropologie, 80: 39-64.

Jelinek, J. (1993) Dismembering, filetting and evisceration of human bodies in a Bronze Age site in Moravia, Czech Republic. Antbropologie, XXXI: 99114.

Jenks, A.E. (1930) Archeological fieldwork of the University of Minnesota in 1930. Science, LXXII: $622-623$.

Jenks, A.E. and Johnson, E. (1992). In: Alonzo Pond and the 1930 Logan Museum Expedition to North Africa: The 1985 Beloit College Symposium (edited by L.B. Breitborde). Logan Museum Bulletin (new series), 1: 45-48.

Kuijt, I. (1996) Negotiating equality through ritual: A consideration of Late Natufian and Prepottery Neolithic A period mortuary practices. Journal of Antbropological Archaeology, 15: 313-336.

Larsen, C.S. (1997) Bioarchaeology-Interpreting Behavior from the Human Skeleton. Cambridge: Cambridge University Press.

Larsson, L. (1984) The Skateholm Project. A Late Mesolithic settlement and cemetery complex at a southern Swedish bay. Papers of the Archaeological Institute, University of Lund 1983-1984 (new series), 5: 5-38.

Larsson, L. (1990) The Mesolithic of Southern Scandinavia. Journal of World Prebistory, 4: 257-309.
Lourandos, H. (1997) Continent of Hunter-Gatherers: New Perspectives on Australian Prehistory. Cambridge: Cambridge University Press.

Lubell, D., Hassan, F.A., Gautier, A. and Ballais, J.-L. (1976) The Capsian escargotières. Science, 191: 910-920.

Lubell, D., Gautier, A., Leventhal, E.T., Thompson, M., Schwarcz, H.P. and Skinner, M. (1982-1983) Prehistoric cultural ecology of Capsian escargotières, Part II: report on investigations conducted during 1976 in the Bahiret Télidjène, Tebessa Wilaya, Algeria. Libyca, 32-33: 59-142.

Lubell, D., Sheppard, P. and Jackes, M. (1984) Continuity in the Epipaleolithic of Northern Africa with emphasis on the Maghreb. Advances in World Arcbaeology, 3: 143-191.

Lubell, D. (1984) Paleoenvironments and Epipaleolithic economies in the Maghreb (ca. 20,000 to 5,000 B.P.). In: From Hunters to Farmers: Considerations of the Causes and Consequences of Food Production in Africa (edited by J.D. Clark and S. Brandt). Berkeley: University of California Press, 41-56.

Lubell, D. (1992) Following Alonzo's trail: paleoeconomic research in Algeria since 1930. In: Alonzo Pond and the 1930 Logan Museum Expedition to North Africa: The 1985 Beloit College Symposium (edited by L.B. Breitborde). Logan Museum Bulletin (new series), 1: $49-57$.

Lyman, R.L. (1987) Archaeofaunas and butchery studies: a taphonomic perspective. Advances in Archaeological Method and Theory, 10: 249-337.

McKinley, J.I. (1993) A decapitation from the Romano-British cemetery at Baldock, Hertfordshire. International Journal of Osteoarchaeology, 3: 41-44.

Molleson, T. (1981) The archaeology and anthropology of death: what the bones tell us. In: Mortality and Immortality - The Antbropology and Archaeology of Death (edited by S.C. Humphreys and H. King). London: Academic Press Inc., 15-32.

Pond, A.W., Romer, A.S. and Cole, F.C. (1928) A contribution to the study of prehistoric man in Algeria. Logan Museum Bulletin, 1.

Pond, A.W., Chapuis, L., Romer, A.S. and Baker, F.C. (1938) Prehistoric habitation sites in the Sahara and North-Africa. Logan Museum Bulletin, 5.

Pond, A.W. (1938) The snail eater and the escargotières. In: Prebistoric Habitation Sites in the Sabara and North-Africa (edited by A.W. Pond, L. Chapuis, A.S. Romer and F.C. Baker). Logan Museum Bulletin, 5: $95-144$.

Potts, R. and Shipman, P. (1981) Cutmarks made by stone tools on bones from Olduvai Gorge, Tanzania. Nature, 291: 577-580.

Roche, J. (1963) LEepipaléolithique Marocaine. Lisbon: Fondation Calouste Gulbenkian. 
Rose, J.J. (1983) A replication technique for scanning electron microscopy: applications for anthropologists. American Journal of Physical Antbropology, 62: $255-261$.

Russell, M.D. and LeMort, F. (1986) Cutmarks on the Engis 2 calvaria? American Journal of Pbysical Antbropology, 69: 317-323.

Russell, M.D. (1987) Mortuary practices at the Krapina Neandertal site. American Journal of Pbysical Antbropology, 72: 381-397.

Sheppard, P.J. and Lubell, D. (1990) Early Holocene Maghreb prehistory: an evolutionary approach. Sabara, 3: 63-69.

Sheppard, P.J. (1987) The Capsian of North Africa: stylistic variation in stone tool assemblages. BAR International Series 353, Oxford: British Archaeological Reports.

Sheppard, P.J. (1992) Snail shells and paradigms: the role of the Logan Museum Expedition in North African Prehistory. In: Alonzo Pond and the 1930 Logan Museum Expedition to North Africa: The 1985 Beloit College Symposium (edited by L.B. Breitborde). Logan Museum Bulletin (new series), 1: 33-44.

Shipman, P. and Rose, J. (1983a) Early hominid hunting, butchering, and carcass-processing behaviors: approaches to the fossil record. Journal of Antbropological Archaeology, 2: 57-98.

Shipman, P. and Rose, J. (1983b) Evidence of butchery and hominid activities at Torralba and Ambrona: an evaluation using microscopic techniques. Journal of Archaeological Science, 10: 465-474.

Shipman, P. and Rose, J.J. (1984) Cutmark mimics on modern and fossil bovid bones. Current Anthropology, 25: 116-117.

Shipman, P. (1981) Applications of scanning electron microscopy to taphonomic problems. In: The Research Potential of Anthropological Museum Collections (edited by A.M. Cantwell, J.B. Griffin and N. Rotschild). Annals of the New York Academy of Science, 376: 357-385.

Shipman, P. (1986) Scavenging or hunting in early hominids: theoretical framework and tests. American Antbropologist, 88: 27-43.
Tarabulski, M. and Teicher, B. (1986) Reliving the Past: Alonzo Pond and the 1930 Logan African Expedition. Video; Beloit, WI: Museums of Beloit College.

Tixier, J., Marmier, F. and Trécole, G. (1976) Le Campement Prébistorique de Bordj Mellala, Ouargla, Algérie. Paris: Éditions du Cercle de Recherches et d'Études Préhistoriques.

Tixier, J. (1955) Les abris sous roche de Dakhlat es-Saâdane (Commune mixte de Bou-Saâda). I. Les industries en place de l'Abri B. Libyca, III: $81-128$.

Trinkaus, E. (1985) Cannibalism and burial at Krapina. Journal of Human Evolution, 14: 203-216.

Ullrich, H. (1982) Artificial injuries on fossil human bones and the problem of cannibalism, skull-cult, and burial rites. Anthropos (Brno), 21: 253-262.

Vallois, H.V. (1971) Le crâne-trophée capsien de Faïd Souar II, Algérie (Fouilles Laplace, 1954). L'Antbropologie (Paris), 75: 191-220, 397-414.

Vernet, R. (1995) Climats Anciens du Nord de l'Afrique. Paris: L'Harmattan.

Villa, P., Bouville, C., Courtin, J., Helmer, D., Mahieu, E., Shipman, P., Belluomini, G. and Branca, M. (1986) Cannibalism in the Neolithic. Science, 233: 431-437.

Villa, P. (1992) Cannibalism in prehistoric Europe. Evolutionary Antbropology, 1: 93-104.

White, R., Ehrhardt, K. and Tarabulski, M. (1992) Extant research resources for the study of North African archaeological collections in the Logan Museum of Anthropology, Beloit College. In: Alonzo Pond and the 1930 Logan Museum Expedition to North Africa: The 1985 Beloit College Symposium (edited by L.B. Breitborde). Logan Museum Bulletin (new series), 1: 59-66.

White, T.D. (1986) Cutmarks on the Bodo cranium: a case of prehistoric defleshing. American Journal of Pbysical Antbropology, 69: 503-509.

Wilson, M.C. (1982) Cut marks and early hominids: evidence for skinning. Nature, 298: 303. 